\title{
From Bipotent Neuromesodermal Progenitors to Neural-Mesodermal Interactions during Embryonic Development
}

\author{
Nitza Kahane and Chaya Kalcheim *(D)
}

check for updates

Citation: Kahane, N.; Kalcheim, C. From Bipotent Neuromesodermal Progenitors to Neural-Mesodermal Interactions during Embryonic Development. Int. J. Mol. Sci. 2021, 22, 9141. https://doi.org/10.3390/ ijms22179141

Academic Editor: Vladimir Trifonov

Received: 4 August 2021

Accepted: 23 August 2021

Published: 24 August 2021

Publisher's Note: MDPI stays neutral with regard to jurisdictional claims in published maps and institutional affiliations.

Copyright: (C) 2021 by the authors Licensee MDPI, Basel, Switzerland. This article is an open access article distributed under the terms and conditions of the Creative Commons Attribution (CC BY) license (https:/ / creativecommons.org/licenses/by/ $4.0 /)$.
Department of Medical Neurobiology, Institute of Medical Research Israel-Canada (IMRIC) and the Edmond and Lily Safra Center for Brain Sciences (ELSC), Hebrew University of Jerusalem-Hadassah Medical School, P.O. Box 12272, Jerusalem 9112102, Israel; nitzakahane@gmail.com

* Correspondence: kalcheim@cc.huji.ac.il

\begin{abstract}
To ensure the formation of a properly patterned embryo, multiple processes must operate harmoniously at sequential phases of development. This is implemented by mutual interactions between cells and tissues that together regulate the segregation and specification of cells, their growth and morphogenesis. The formation of the spinal cord and paraxial mesoderm derivatives exquisitely illustrate these processes. Following early gastrulation, while the vertebrate body elongates, a population of bipotent neuromesodermal progenitors resident in the posterior region of the embryo generate both neural and mesodermal lineages. At later stages, the somitic mesoderm regulates aspects of neural patterning and differentiation of both central and peripheral neural progenitors. Reciprocally, neural precursors influence the paraxial mesoderm to regulate somite-derived myogenesis and additional processes by distinct mechanisms. Central to this crosstalk is the activity of the axial notochord, which, via sonic hedgehog signaling, plays pivotal roles in neural, skeletal muscle and cartilage ontogeny. Here, we discuss the cellular and molecular basis underlying this complex developmental plan, with a focus on the logic of sonic hedgehog activities in the coordination of the neural-mesodermal axis.
\end{abstract}

Keywords: cell differentiation; dermomyotome; floor plate; lateral plate mesoderm; motoneurons; muscle; neural tube; notochord; sclerotome; somite

\section{Introduction}

Mesoderm formation is a multistage process. Mesoderm induction begins during gastrulation and leads to formation of the rostralmost somites. Subsequently, mesoderm induction continues after gastrulation in a special cell population termed neuromesodermal progenitors (NMPs). NMPs are located in a caudal embryonic structure, the tailbud, and represent a common pool of bipotent progenitors able to generate caudal spinal cord neurectoderm and paraxial mesoderm tissues [1,2]. As such, they are identified by the coexpression of transcription factors that characterize gastrulation, mesoderm, and neural development such as T(Brachyury), Sox2 and Nkx1/2 [3,4]. Hence, the reciprocal interactions between separate neural and mesodermal derivatives that portray patterning and morphogenetic phases of later development essentially begin early in life in the form of a common lineage.

Derivatives of NMPs comprise the paraxial mesoderm and the neural tube (NT) at spinal cord levels. Notably, human pluripotent stem cells induced in vitro to generate trunklike NC progenitors revealed a transient intermediate neural crest (NC)/NMP state expressing both early NC (Msx1/2, Pax3, Zic1/3) and NMP markers (Bra, Sox2, Msgn1) [5-7]. More recently, using a trunk-specific foxd 3 enhancer to trace the lineage of NC cells in vivo, tailbud NMPs were also labeled. Subsequently, labeling was encountered in cells that express neural plate border and early NC genes and in neuronal trunk derivatives such as 
dorsal root ganglia [8]. Together, these results suggest that at least some trunk-level NC progenitors also derive from NMPs.

Here, we briefly and separately introduce the three interacting players in trunk patterning and morphogenesis: the paraxial mesoderm, the NT and the NC. In the forthcoming sections, we elaborate on the molecular nature of interactions between these components and on their developmental outcomes.

\subsection{Paraxial Mesoderm}

Mesenchymal cells of the nascent paraxial mesoderm (the segmental plate) undergo a process of mesenchymal-to-epithelial transition and segment into metameric units, the somites. Recently formed epithelial somites are already heterogeneous structures, differing in properties between medial vs. lateral, and rostral vs. caudal domains [9-11]. These differences are determined, respectively, by graded mediolateral BMP signaling and by the dynamic rostrocaudal properties imparted by the segmentation clock $[12,13]$. In addition, dorsoventral differences in the somite, conveyed by notochord (No)-derived sonic hedgehog (Shh) signaling ventrally and by ectoderm-derived Wnt signaling dorsally, determine the segregation into ventral sclerotome and dorsal dermomyotome lineages, respectively, a process that becomes fully apparent upon epithelial-to-mesenchymal transition (EMT) of the former. Sclerotomal cells undergo further morphogenetic changes and form the vertebrae and ribs [10,14]. Dermomyotome precursors segregate into a variety of derivatives that include epaxial muscles of the back, hypaxial muscles of the body wall and limbs [11,15-19], a set of mitotic myoblasts [20], part of which generate differentiated muscle while others remain as Pax7-positive satellite cells [21-23], dorsal dermis [18,24], scapula blade at flank levels of the axis [25] and endothelial cells (reviewed in [11].

In addition to the well-established myogenic capacity of all domains of the dermomyotome (four lips and central sheet), an earlier myogenic domain comprising the medial epithelial somite was recognized years ago. It consists of a specialized group of early post-mitotic progenitors which in avian embryos, express both MyoD and Myf5. During the process of somite dissociation, these cells bend underneath the forming dermomyotome and upon delamination and slit-robo-dependent migration in the caudal to rostral direction, they differentiate into the first segmental myofibers. Together with the later contributions from the dermomyotome, they constitute the primary postmitotic myotome composed of unit-length fibers [[26-29] and reviewed in [30]].

\subsection{Neural Tube}

The NT generates the brain and spinal cord components of the central nervous system (CNS). Initially, it has a relatively simple architecture, arising when the neural plate folds to form a tube at rostral regions of the axis (primary neurulation) [31], or by secondary neurulation, that involves a mesenchymal-to- epithelial transition of NMPs to form a cord-like structure at more caudal regions of the axis. Cavitation of this cord then generates an epithelial NT [32,33], a process partially dependent on TGF $\beta$ and yes-associated protein (YAP) signaling [34].

In both cases, the resulting NT consists of a pseudostratified epithelium, which is only one cell thick at the earliest stages. Its dividing cells are the progenitors for all of neurons and glia. At spinal cord levels, differentiating progenitors, that completed mitosis at the ventricular (apical) domain of the neuroepithelium, migrate basally yielding a laminar structure that contains postmitotic neuronal cell bodies (mantle layer); these send their processes towards an outer marginal layer [35-38].

The spinal cord also exhibits a remarkable organization along its dorsoventral extent. Neural populations are specified by inductive signaling from opposing poles, the floor plate and the dorsal NT which later becomes the roof plate. The ventral floor plate is induced by signals from the underlying No [39], a transient mesodermal structure that later becomes the nucleus pulposus within the intervertebral disk [40]. No and floor plate produce and release Shh that acts in a graded spatial and temporal fashion to induce 
different cell types in the ventral spinal cord [41-43]. These comprise at least five progenitor (p) domains, $\mathrm{p} 0-\mathrm{p} 3$ and the $\mathrm{pMN}$, which give rise to five distinct cell types, the ventral (V) IN, V0-V3 and motoneurons (MNs) [44-47]. The dorsal spinal cord contains at least six dorsal progenitor $(\mathrm{dP})$ domains, $\mathrm{dP} 1-\mathrm{dP} 6$, that differentiate into the dorsal interneuron populations 1-6 [36]. These are patterned by BMP and Wnt morphogens initially derived from the dorsal NT and later from the roof plate itself which likely affects subsequent aspects of interneuron differentiation [48-52]. Notably, retinoic acid (RA) from the adjacent paraxial mesoderm was also shown to influence diverse aspects of NT development along the entire dorsoventral extent of the neuroepithelium $[47,53,54]$.

Under the influence of these morphogens, distinct domains of progenitors are generated that express a unique combination of transcription factors specifying their identities. Then, a cross-inhibitory talk between cells expressing the above factors further refines the pattern and leads to formation of discrete populations of neurons, as described above. This combinatorial network of transcription factors not only regulates progenitor cell position and patterning, but also further differentiation and later connectivity and function [55].

\subsection{The Neural Crest}

The development of the dorsal NT is of particular interest as in addition to generating specific components of the CNS, it is also the source of NC progenitors that yield most of the peripheral nervous system as well as of additional non-neural derivatives such as melanocytes, ectomesenchyme and endocrine cells [56]. In fact, three cell populations sequentially form in the dorsal NT. First, NC cells that actively proliferate, undergo EMT, leave the NT and engage in migration as mesenchymal cells [56,57]. Second, roof plate cells, which exit the cell cycle, regain epitheliality and baso-apical polarity $[58,59]$. Third, spinal interneurons whose specification and/or differentiation are induced by the roof plate that acts as an organizing center (Section 1.2) [60].

Growing evidence substantiates the significance of interactions between the above NMP derivatives; from NT patterning and differentiation of specific cell types to induction of NC cells, control of NC emigration and migration followed by peripheral nervous system segmentation, all of which are modulated by mesodermal signals. Reciprocally, survival and proliferation of paraxial mesoderm, control of myogenesis and chondrogenesis are elicited by NT, NC and No-derived factors. The molecular basis of these processes is discussed in the next sections.

\section{Factors Underlying the Choice of NMPs to Generate Neural or Mesodermal Fates}

NMPs are Sox2+/Brachyury+ cells that form the bulk of neural and paraxial mesoderm progenitors of the posterior trunk region [2]. Whether NMPs constitute a population of bipotent cells or alternatively, a mixture of precursors separately committed to each lineage remained unclear. Recent lineage tracing in the chick embryo using a barcoded retroviral library and the Brainbow method for in vivo clonal analysis, revealed a resident cell population, mapped to the anterior primitive streak epiblast, that contains single cells contributing to both neural and mesodermal lineages in trunk and tail, and further characterized their dynamics and molecular profile [61]. NMPs can either self-renew to maintain the bipotent state, or differentiate either as paraxial mesoderm or neuroectoderm. Most notably, the principal molecular components of the network regulating the progenitor state and its differentiation are conserved across species. They include canonical Wnt, FGF, and RA acting in combination with the transcription factors T (Brachyury), Tbx6 and Sox2.

In zebrafish, FGF plays a dual role, it activates Brachyury in the early gastrula, but it represses both Brachyury and Sox 2 at the later NMP stage. Consequently, cells commit to a mesodermal fate, a process resulting from the coordinated activities of Wnt signaling, responsible for cellular epithelial-to-mesenchymal transition (EMT), and FGF that ends the process [62]. Kinney et al. [63], showed the existence of a developmental checkpoint during mesoderm induction, ensuring that Sox2-expressing cells do not migrate into the mesoderm by maintaining a partial EMT state [64]. The underlying mechanism involves 
synergy between Sox 2 and the mesoderm-inducing Wnt pathway. When Wnt signaling was inhibited in Sox2-expressing cells the latter entered the mesoderm while keeping a partial EMT configuration, and formed an ectopic spinal cord instead of the mesoderm [63]. This checkpoint was interpreted to be critical for preventing ectopic spinal cord formation in place of the mesoderm, thus coordinating morphogenetic movements with proper cell fate acquisition.

Consistently, loss of either Brachyury, Tbx6, Fgfr1 or Wnt3a leads both to shortened axes, and the ectopic production of neural tissue at the expense of somitic mesoderm [65-68]. Lineage-tracing studies in mouse mutants lacking Wnt $3 \mathrm{a} / \beta$-catenin signaling provided genetic evidence that trunk progenitors normally fated to enter the mesoderm can be redirected towards the neural lineage. This further substantiated the notion that Wnt3a/ $\beta$-catenin signaling directs trunk progenitors towards a paraxial mesoderm fate. To note is, that in the same study, the authors additionally found that Wnt3a positively supports maintenance of the dual progenitor state [69]. Along this line, during midtrunk formation, Wnt/ $\beta$-catenin signaling was shown to expand the number of Sox $2+\mathrm{T}+\mathrm{NMPs}$ and maintain the appropriate level of Brachyury in the NMP population [70].

In contrast, RA was shown to promote neural differentiation of NMPs [reviewed in [4]]. Mouse Raldh2-/- embryos, lacking RA synthesis, exhibited decreased Sox2+ and Sox1+ neuroectodermal progeny and increased Tbx6+ presomitic mesodermal progeny. In addition, somites were smaller in these mutants due to ectopic caudal FGF8 activity. This Raldh2-/- small somite defect was rescued by treatment with an FGF receptor antagonist, suggesting that RA activity in undifferentiated neural progenitors is sufficient to restrict caudal Fgf8 expression in both neuroectoderm and mesoderm and hence control neurogenesis as well as somite size. Thus, the inhibitory cross-talk between RA and FGF accounts for the coordination of somitogenesis with neurogenesis [71].

RA and Wnt signals also stand in an inhibitory interaction. Using single-cell transcriptomics, Gouti et al. [72], identified the molecular signature of mouse NMPs, and together with genetic perturbations, the authors uncovered a transcriptional network and feedback interactions that integrate these opposing activities to regulate the bifurcation of neural and mesodermal fates. RA, whose levels are tightly regulated in the tailbud region both by synthesis and degradation, was found to play a dual role. First, it induces NMPs. As cells leave the NMP zone they differentiate to mesoderm progenitors expressing Bra/Msgn1/Tbx6, which results in upregulation of Aldh1a2, the RA-synthesizing enzyme. In turn, increased synthesis of RA in nascent mesodermal cells located in proximity to the niche promotes Sox 2 expression and the progressive differentiation of NMPs to neural progenitors [72].

\section{Mutual Interactions between Neural and Mesodermal Progenitors Shape the Body Plan}

\subsection{Mesoderm-Neural Tube Interactions}

A close spatial correlation is observed in zebrafish embryos between the repetitive pattern of motoneuron progenitor distribution in the NT and the changing architecture of the adjacent somites, suggesting that signals from paraxial mesoderm specify different motoneuron subtypes. Results of grafting experiments confirmed this notion [73,74]. Furthermore, motoneuron specification was disturbed in spadetail (spt) as well as in additional zebrafish mutants, all exhibiting defective formation of the trunk paraxial mesoderm [75-79]. Additionally, heat-shock-induced defects in somite segmentation altered the position of motoneurons and their axonal morphology $[80,81]$.

Furthermore, in avian embryos, the progression of neurogenesis in the NT is subservient to the dynamics of paraxial mesoderm development. Whereas presomitic mesoderm and FGF signaling maintain expression of caudal neural genes in the prospective spinal cord, neuronal differentiation is repressed by them and induced instead by factors emanating from the segmented somites. Inhibition of FGF activity was not sufficient to promote neuronal differentiation, suggesting the need for additional somite-derived factors [82]. RA was later identified as the somitic signal that antagonizes FGF and stands 
in a reciprocal gradient of expression along the rostrocaudal axis. By attenuating Fgf8 activity in both neuroepithelium and paraxial mesoderm, RA controls the positioning of somite boundaries, expression of ventral neural patterning genes and neuronal differentiation, thereby coordinating a neural-mesodermal cross-talk [54]. Thus the RA/FGF antagonism is a reiterative motif during early fate choices of NMPs and later once mesoderm and neuroectoderm are established as separate entities.

The recurring roles of the same set of factors throughout development, impose the need for analysis of neural-mesodermal interactions at specific stages and time windows, a technically challenging task in mammalian embryos. To overcome these limitations Veenvliet et al. [83] produced highly organized "trunk-like structures" comprising both NT and somites from pluripotent mouse embryonic stem cells. Upon embedding in extracellular matrix, cell aggregates initially formed, which then self-organized and segregated into these two main tissues. Comparative single-cell RNA sequencing analysis confirmed that this in vitro process resembles molecularly the progressive development of the mouse trunk. As a proof of concept, the authors implemented compound organoids in which mesodermal Tbx6 was knocked out. These structures developed additional NTs, similar to the embryo mutants, further confirming the role of mesodermal factors in neural patterning, and providing a promising platform for future research on tissue interactions. Reciprocally, somite patterning requires signals from adjacent cell types as revealed by grafting experiments in chicks. For example, the paraxis gene, important for maintaining somite epitheliality, is first expressed in epithelial somites and then in the dermomyotome. Paraxis is a target for signals released from ectoderm and/or NT [84]. Additional signals operating between somitic and NT tissues involve a third cell type, the NC, and will be discussed in the next section.

\subsection{Interactions between NT and Somites Control Multiple Aspects of NC Development}

\subsubsection{NC Induction}

Formation of the NC is influenced by interactions with mesodermal tissue [see [85-87] for comprehensive reviews]. The dorsolateral marginal zone (DLMZ) of the Xenopus gastrula that generates paraxial and intermediate mesoderm is the source of NC-inducing signals, as revealed by recombination experiments [88-90]. Further maintenance of NC markers was also shown to require paraxial mesoderm [88,91]. The DLMZ expresses multiple Wnt and FGF ligands and the BMP antagonist Chordin [88,89,92,93], likely to mediate these events. Likewise, in avians, recombination between nascent neural tissue and somites or lateral mesoderm also generated NC-derived melanocytes [94].

\subsubsection{The Timing of NC EMT}

A significant body of evidence, primarily stemming from avian embryos, relates the onset of NC migration in the trunk with somitogenesis and subsequent somite dissociation [95-97]. This suggested that the paraxial mesoderm regulates aspects of NC EMT and emigration.

An interplay between noggin and BMP4 in the dorsal NT generates a graded activity of BMP that, via regulation of Wnt1 transcription and Wnt-dependent canonical signaling, triggers delamination of NC progenitors and the consequent onset of cell migration [98,99]. This rostral-to-caudal gradient of BMP4 activity is generated in spite of a constant level of BMP4 mRNA production along the dorsal NT by virtue of an opposing, decreasing gradient of noggin transcription and activity that correlates with somite development. Downregulation of noggin progressively relieves inhibition of BMP and allows NC EMT. Somitic factors were suggested to influence the levels of noggin mRNA in the NT. Consistent with this notion, grafting experiments revealed that dissociating, but not younger somites, emit an inhibitor of noggin production in the dorsal NT, thereby coupling the time of EMT with the development of the somites as suitable substrates for subsequent NC migration [100]. Opposing gradients of FGF8 and RA, apparent in the paraxial mesoderm, were reported to control the timing of NC EMT, in part through the modulation of specific aspects of BMP 
and Wnt signaling [101] (Figure 1A). These results further exemplify the importance of reiterative molecular modules as mediators of the dynamics of trunk development.

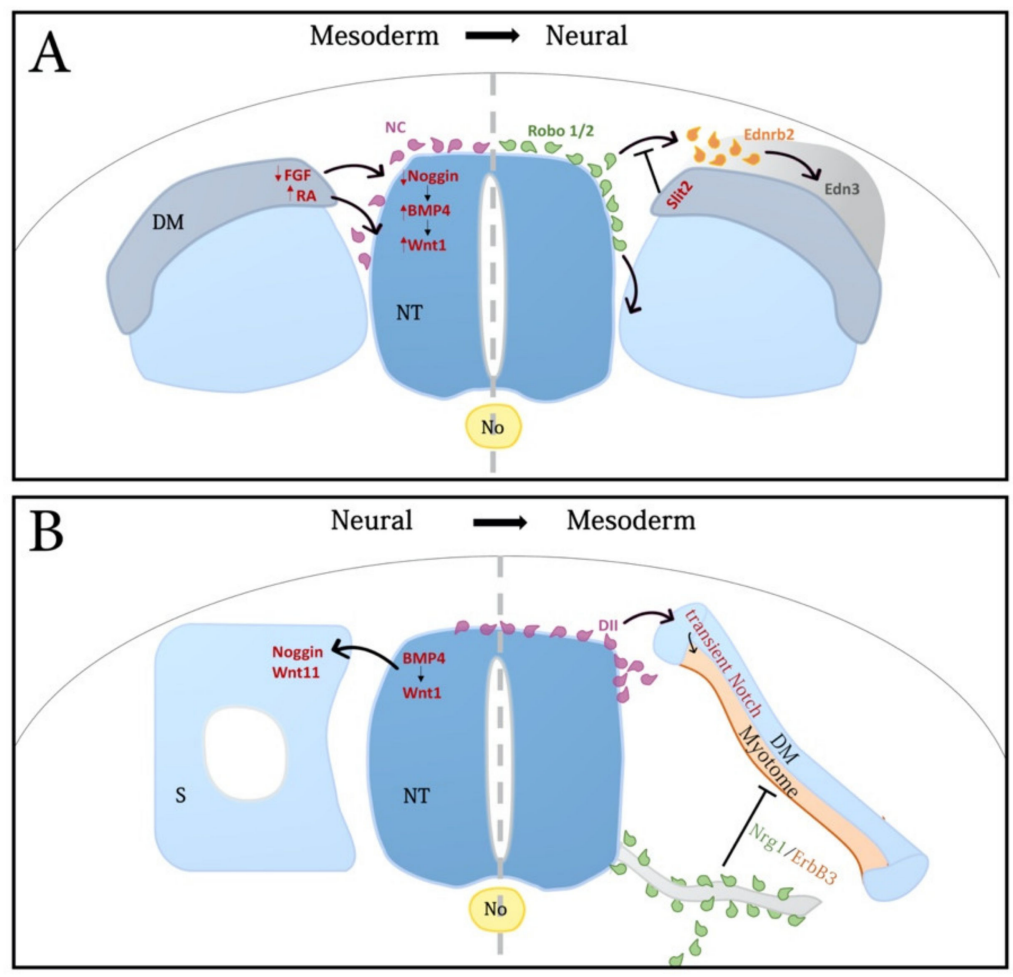

Figure 1. NC-mesoderm interactions. (A) Left side: The medial lip of the nascent dermomyotome (DM) controls the timing of NC delamination. In the early dorsal neural tube (NT), prior to the onset of NC emigration, levels of noggin are high, in part due to somite-derived FGF signaling, thereby inhibiting the activity of BMP4 and consequent NC delamination. During somite dissociation, decreasing FGF signaling results in reduced transcription of noggin in the dorsal NT. Consequently, inhibition on BMP4 is relieved, Wnt1 transcription is stimulated and NC emigration is set in motion. In parallel, increasing retinoic acid (RA) levels in the DM act upon the dorsal NT to induce Wnt1 and trigger NC cell emigration (purple cells). (A) Right side: The DM and later dermis influence the choice of pathways followed by NC cells. During the early stage of NC migration, DM cells express the secreted ligand Slit2, which acts upon Robo1/2-expressing NC cells (green) to prevent them from entering prematurely the dorsolateral pathway. At a later stage of migration, the Edn3 ligand, expressed in the somite-derived dermis and in the ectoderm attracts melanoblasts (yellow) that express the Ednrb2 receptor following delamination from the neural tube; this interaction guides them into the dorsolateral pathway. (B) Left side: The dorsal neural tube (NT) patterns the medial DM. NT-derived Bmp4 and Wnt1 signal the adjacent dorsal somite (S) to promote a medial identity, the development of the medial lip of the DM, and the expression of genes such as noggin and Wnt11, respectively. (B) Right side: Migrating NC cells regulate myogenesis. Migrating NC cells (purple) contact the dorsomedial lip of the DM and signal through Delta1 (Dll) to transiently activate Notch in the DM; this results in enhanced myogenesis at the expense of Pax7-positive progenitors in the epithelium. Migrating NC cells fated to become Schwann cells (green) along peripheral nerves signal through Nrg1/ErbB3 to the central and hypaxial DM and myotome (pink) to maintain the progenitor state while inhibiting myogenic differentiation. Stippled grey lines separate the NT in halves to illustrate different processes in each. See text for details and references. Abbreviations: No, notochord; Scl, sclerotome.

\subsubsection{Segmental Migration of NC and Patterning of the PNS}

The PNS of higher vertebrates is segmented to align the peripheral ganglia and nerves with the vertebrae. This pattern is established during embryogenesis, when vertebrae develop from the somite-derived sclerotome and NC cells preferentially migrate into 
the rostral sclerotome halves. Grafting experiments in avian embryos showed that the metameric arrangement of the PNS depends upon the rostro-caudal alternation of sclerotomal properties [102-105], and so is the development of specific components of the vertebrae $[106,107]$. Several gene families were shown to mediate segmental NC migration primarily through repulsive interactions between caudal sclerotome and NC cells; these include Eph and ephrins, F-spondin, neuropilins and semaphorins, T-cadherin, etc. [108-114]. Whereas some of the pathways operate sequentially, others might act cooperatively as part of a regulatory network that ensures proper segmental patterning. Notably, to date, no experiments that examined the existence of such a network have been published.

\subsubsection{Melanoblast Migration along the Dermomyotome-Derived Dermis}

The latest NC cells to exit the NT produce melanocytes and migrate along a dorsolateral pathway through the nascent dermis [115]. These NC-derived melanocytes colonize the epaxial region of the body and their patterning results from a close interaction between the NC progenitors and somite-derived dermis [116]. It is worth mentioning that earlyemigrating Schwann cell progenitors are also an important source of melanocytes yet they differentiate later and are restricted to the hypaxial body domain including limbs [116,117].

The choice of ventral vs. lateral migration pathways seems also to depend on somitic factors. Dermomyotome-derived Slit2 represses the entry of Robo-expressing NC cells into the lateral pathway thus confining the migration of early NC cells to the ventral route [118] (Figure 1A). Additional repulsive cues are present in both the caudal sclerotome and the dorsolateral pathway such as ephrins, F-spondin, chondroitin sulfate proteoglycans and PNA-binding molecules [111,119-121]. On the other hand, positive chemotactic guidance molecules such as the Ednrb2 and EphB2 receptors [122] were identified. Ednrb2 is upregulated in melanoblasts prior to entering the dorsolateral domain, and endothelin3 (ET3), its ligand, is expressed by cells of the ectoderm, dermomyotome and the mesenchymal dermis [123-126] (Figure 1A). Of interest is that even if initiation of dorsolateral migration follows the appearance of the dorsal dermis, misexpression of Ednrb2 in NC progenitors at earlier stages is sufficient for driving cell migration prematurely between ectoderm and epithelial dermomyotome [125]. Possibly, high levels of the Ednrb2 receptor are dominant over inhibitory cues present in the superficial pathway at early stages.

\subsection{NC-Mesoderm Interactions in the Regulation of Myogenesis}

An extensive crosstalk between NC cells and the adjacent mesoderm was recognized at all levels of the neuraxis. In the head, sequential interactions between NC and the cranial mesoderm shape craniofacial morphogenesis, development of the musculature and aspects of mutual cell differentiation [127-135].

In the trunk, NT/NC-somite interactions play a fundamental role in development of somite derivatives. The early dorsal NT regulates specific aspects of dermomyotome development through BMP4 activity [136], as well as subsequent formation of the dorsal dermis through neurotrophin 3 [137]. In addition, Wnt signals pattern the medial dermomyotome [138-142], and Wnt1 from the dorsal NT acts through the canonical pathway to control expression of Wnt11 in the medial dermomyotome, which in turn orients myocyte elongation [143] (Figure 1B).

Early migratory NC cells, transiently contacting the medial dermomyotome, provide promyogenic signals via activation of the Notch pathway [144]. Furthermore, NC-derived Neuregulin1 acting through the ErbB3 receptor, regulates murine muscle development by maintaining the Pax7-positive progenitor pool and preventing premature myogenic differentiation [145] (Figure 1B) [highlighted in [146]]. 


\section{Shh, an Axial Midline Morphogen, Is Essential for Neural and Mesodermal Development}

Shh is a well-studied morphogen, that plays essential roles in development of both NT and somites [44,147-151]. Signaling by this ligand is initiated by binding to the transmembrane receptor patched (Ptc), that represses the pathway in its absence and is also a direct transcriptional target of Shh [152,153]. Ligand binding to Ptc reveals repression on smoothened, a key effector essential for hedgehog signal transduction [154]. Transduction of Shh signaling is believed to take place in apically localized cilia where a dynamic behavior of Ptc and smoothened was documented to modulate Gli transcriptional activity [155-160]. Shh signaling is highly regulated by negative and positive modulators. In addition to Ptc1, hedgehog interacting protein (Hhip) and Gli1 are also direct targets of Shh and the former two also inhibit its activity [161,162]. Sulfatase1 [163], Boc, Gas and Cdo $[164,165]$ enhance ligand activities and are expressed in NT and/or developing mesoderm [166].

Shh is synthesized and secreted by the No and then also the floor plate of the NT. Its functions as a morphogen are exemplified by induction of distinct ventral cell identities in the overlying NT via a mechanism that depends on relative concentrations and duration of exposure $[43,167,168]$. Likewise, a concentration gradient of Shh was suggested to control the in vitro induction of sclerotome and myotome $[149,166]$. Moreover, its activity continues beyond the patterning stage to regulate cell proliferation, survival and differentiation in both systems [[169,170], and see below].

\subsection{Shh in Muscle Development}

In zebrafish, different levels and durations of Shh signaling specify distinct myotomal cell types [162,171-174]. No-derived Shh is also involved in regulating mesoderm precursor cell survival, proliferation, and differentiation. In the chick, surgical ablation of the NT and No strongly affected epaxial muscle, vertebrae and rib formation due to cell death in the somites. Notably, grafting of either the ventral NT or the No, or even of cells secreting Shh in place of the deleted axial organs rescued formation of epaxial muscles, ribs and vertebrae. These results suggested that Shh emanating from the floor plate and/or the No is required for survival of both myogenic and chondrogenic cell lineages [175]. In addition, Shh regulates Myf5 expression in primary epaxial myoblasts [176], and ectopic application of Shh causes premature myoblast differentiation at the expense of Pax3 expression [15,176-179].

Early muscle formation is actually subdivided into two main phases. An initial patterning phase composed of postmitotic, unit-length myofibers [16-18,27,30,180-182], and a second phase characterized by cell expansion. The latter is associated with dissociation of the central sheet of the dermomyotome that produces dermis and Pax3/7-positive myoblasts. These remain mitotically active within the myotome $[20,183]$ and later in development generate either fibers or satellite cells, the adult muscle stem cells $[21,22,184]$. Using a mouse transgenic line, a ventrodorsal activity gradient of Shh/Gli signaling was directly visualized spreading from the No through the sclerotome [166]. In addition, in chick embryos, specific inhibition of Shh activity in sclerotome, impaired dermomyotome cell proliferation and epitheliality generating smaller dermomyotomes whose epithelial configuration is disrupted, primarily in their central domain (Figure 2B). Furthermore, terminal differentiation of muscle progenitors that entered the primary myotomal domain was significantly reduced with residual Pax7-positive progenitors instead of differentiated myocytes (Figure 2B) [166]. Thus, the sclerotome is an important pathway for Shh transport and distribution to target cells. Notably, somewhat later, dissociating dermomyotome progenitors become refractory to Shh signaling, showing that the activity of Shh is only temporary, thereby allowing a dynamic transition from muscle patterning to growth [166].

\subsection{Shh and Cartilage Development}

The somite-derived sclerotome is not only a pathway for Shh distribution, it is also an important target of activity. The sclerotome is a transient, embryonic tissue composed of mesenchymal cells that derives from the ventromedial region of the somite. The localization 
and specification of the sclerotome is a tightly controlled process stimulated by Shh signaling from the floor plate of the NT and/or No, which induce expression of early sclerotome markers such as Pax1, Pax 9, Nkx3.2 and Mfh1 [14,147,185-187]. Selective inhibition of Shh signaling in the ventral somite results a day later, in formation of smaller sclerotomes, suggesting that Shh is also involved in size control [188]. Similar to the antagonistic activities of BMP and Shh signaling in NT development, in the mesoderm, opposing functions of lateral plate mesoderm-derived BMP and midline-derived Shh allow sclerotome differentiation. To this end, the No not only expresses Shh but also noggin, a powerful BMP antagonist [189].
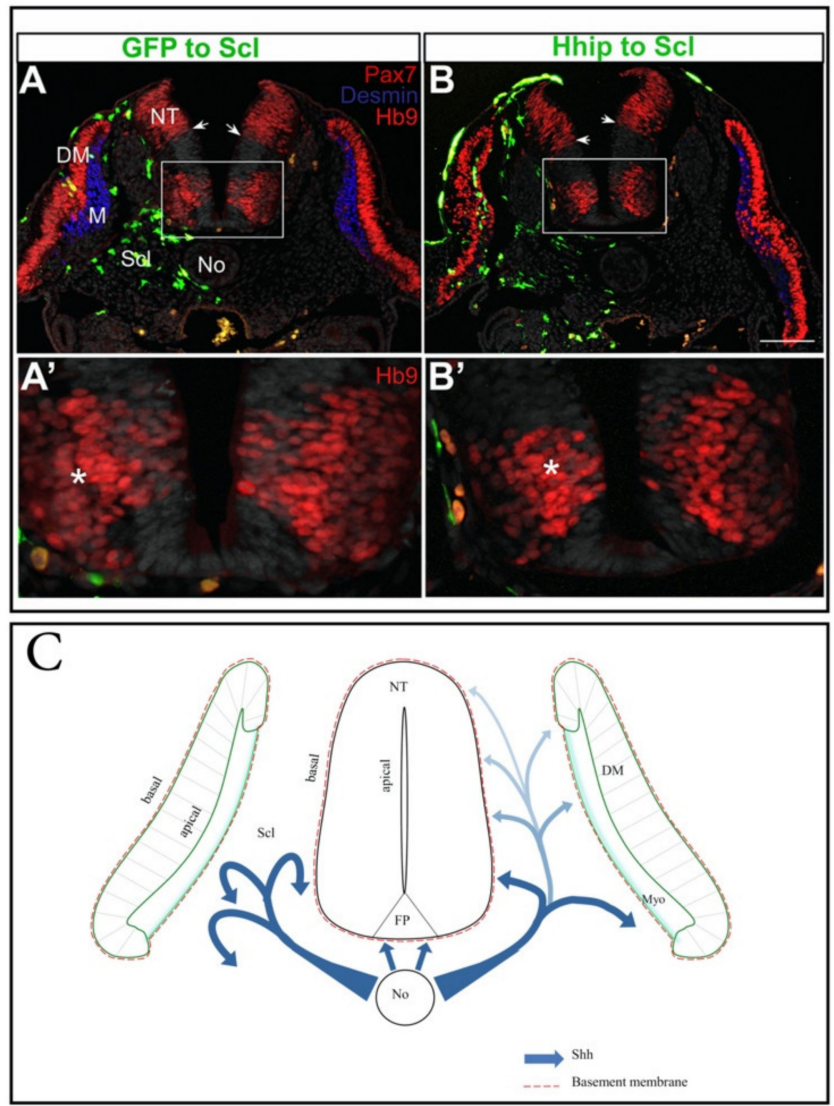

Figure 2. Notochord-derived Shh traversing the sclerotome affects both myotome and motoneuron differentiation. (A,B) Electroporation of control GFP (green) (A) or hedgehog-interacting protein (Hhip1) (green in (B)) to the prospective sclerotome at the flank level of the axis. A day later a reduction in myotome size (blue desmin staining) is apparent adjacent to the transfected cells. In addition, note ventral shift of the Pax7+ boundary in (B) (small arrows) indicative of a dorsalization of NT properties. $\left(\mathbf{A}^{\prime}, \mathbf{B}^{\prime}\right)$ Higher magnification of the insets in $(\mathbf{A}, \mathbf{B})$, respectively, depicting a reduction of $\mathrm{Hb} 9+$ motoneurons in (B) upon Hhip1 treatment compared to the control side and to control GFP $\left(\mathbf{A}^{\prime}\right)$. Asterisks $\left.{ }^{*}\right)$ denote motoneurons adjacent to electroporated sclerotomes. Similar results were obtained with a membrane-tethered Hhip and with Ptc plasmids [see [188] for further details]. (C) A proposed model for the activity of notochord (No)-derived Shh. The No secretes Shh that acts on the ventral neural tube (NT) and also traverses the sclerotome $(\mathrm{Scl})$ which is both a pathway for ligand movement and also a target of its activity. A ventral to dorsal gradient of ligand is created in Scl (blue arrows) [166], that influences both myotome as well as motoneuron development. Shh is thus presented to the target epithelial cells via its basal domain, probably by initial association with the laminin-containing basement membrane (red line). In addition, Shh traversing the sclerotome is also required for aspects of sclerotomal development (blue arrows on left side of image). Scale Bar, $50 \mu \mathrm{M}$. 
The sclerotome forms most components of the axial skeleton: vertebrae, ribs, cartilaginous end plates, the annulus fibrosus, and also tendons and ligaments via an intermediate domain, the syndetome [190-192]. Not surprisingly, being produced by the No, Shh was shown to be necessary for the formation of the sheath encircling the No itself. Removal of Shh signaling resulted in formation of small and dispersed nuclei pulposi, remnants of the primitive No that localize to the middle part of the intervertebral discs. Hence, Shhdependent sheath integrity is probably responsible for maintenance of the rigid, rod-like structure that characterizes the No [193].

As mentioned above, sclerotomal precursors also generate the ribs. Loss of the proximal part of the ribs is observed in Shh null mutants [185], and in mouse mutants depleted of the Shh-dependent sclerotomal marker gene Pax1 [194].

Although midline-derived Shh is necessary both for myotome and sclerotome formation, direct myotome-sclerotome interactions, and subsequent intercostal muscle-rib communication, were also documented as being important for proper rib growth and patterning $[195,196]$. These are likely to take place in a Shh-independent mode.

In this context, it is worth mentioning that neural-skeletal connections also extend into adult life. Neurons of sympathetic, parasympathetic, and sensory branches communicate with cells of the bone microenvironment and regulate bone development, bone mass accrual, bone remodeling, and even spread of metastatic cells. Understanding the precise functions of innervation in the control of bone homeostasis throughout the organism's life span may lead the way to new therapeutic approaches [197].

\subsection{Shh in the Coordination of Neural-Mesodermal Development}

As discussed in the previous sections, the NT and mesoderm are two developmentally and functionally interconnected systems, and Shh plays pivotal, yet time-limited, roles in their establishment. A question stemming from these findings, is whether the effects of Shh on either tissue are independent of each other or interrelated. As for neural development, does the NT receive Shh directly from the producing sources (No and/or floor plate), or given the ligand is released into the mesoderm, can the latter serve as a pathway from which Shh affects aspects of both NT and mesoderm development? Two findings obtained in avian embryos support the latter notion. First, reducing the amount of Shh uniquely in the sclerotome by hedgehog-interacting protein, by a membrane-tethered version of this inhibitor that is unable to diffuse away from transfected cells, or by missexpression of the transmembrane receptor Ptch1, significantly reduced motoneuron numbers and concomitantly reduced myotome development $[166,188]$ (Figure 2A-B'). The observed phenotypes were a specific and direct consequence of Shh depletion. Furthermore, deletion of the floor plate did not affect either process, suggesting that, at a post-neurulation stage, the sclerotome constitutes a dynamic substrate of No-derived Shh that acts both on motoneuron as well as on myotome development. Second, grafting No fragments adjacent to the basal, sclerotomal side of the NT profoundly affected motoneuron development when compared to similar grafts applied in the NT lumen, e.g.; at the apical side. This suggested that active ligand must be presented to the epithelium from its basal side that is in contact with the sclerotome through which Shh transits and that also serves as a pathway to affect muscle and sclerotome development (Figure 2C) [188]. The significance of these findings is twofold: first, it presents a novel pathway through which No-derived Shh disperses to promote aspects of neural development; second, it suggests that by affecting both motoneuron and muscle differentiation, a single ligand coordinates initiation of future neuromuscular organization (Figure 2).

\section{Conclusions and Future Perspectives}

Investigating development of the neural-mesodermal axis enables us to recognize the logic underlying establishment of the body plan. The complex events leading from NMPs to paraxial mesoderm and NT, and ensuing interactions leading to coordinated formation of their respective derivatives, embody most of the basic processes in embryoge- 
nesis, from cell fate decisions to cell proliferation, migration, terminal differentiation and patterned morphogenesis.

Clonal approaches in vitro and in vivo recently showed the bifated nature of NMPs [61] and additional studies begun addressing the molecular network responsible for fate segregation (see Section 2). Much is still to be uncovered regarding the relationship between cell fate acquisition and morphogenesis, by addressing dynamic processes such as EMT and cell migration.

An intriguing question is what NC populations emanate from NMPs [8], are these primarily neural progenitors or also melanocytes? Additional labeling strategies should be implemented to address the lineage of the trunk NC back to these fascinating postgastrulation progenitors, followed by exploring mechanisms of lineage segregation. Advances in protocols for the establishment of compound organoids should complement in vivo approaches, primarily for research into mouse and human systems. These should be useful in uncovering the feedback mechanisms and transcriptional modules operating downstream of Wnt, FGF, and RA and perhaps of additional factors. Clarifying the nature of cross-inhibitory interactions at transcriptional and post-transcriptional levels will enable a better understanding of how different fates are established and further refined.

Another captivating topic concerns the mode of transport of morphogens towards the target cells. In the context of mesoderm-neural interactions, we proposed that a significant fraction of Shh operating on the neuroepithelium stems from the No via a sclerotomal pathway that, at somitic stages, is more active than the floor plate in promoting motoneuron development [188].

How is Shh transported through the sclerotome? Possible models could involve packaging of the ligand in No-derived exosomes [198], diffusion of Shh released by metalloproteinases in a lipid-free form [199], secretion as multimeric complexes [200] and/or via carrier-mediated transport through the extracellular space [201]. The precise mechanism responsible for Shh transport in this context remains to be unraveled.

Although apical cilia act as activity centers of Shh signal transduction, our findings would suggest that neuroepithelial cells sense Shh from their basal pole that faces the sclerotome. This is consistent with enhanced motoneuron differentiation occurring upon basal but not apical presentation of a No under experimental conditions, and also in normal development as the No underlies the basal domain of the NT. Reports in the literature stand in agreement with a basal presentation of both Shh [202] and also BMP/activin [203,204]. In such a case, how is Shh transported through epithelial cells from the basal towards the apical domain where cilia are located and signal transduction takes place? Alternatively, are there cilia-independent modes of ligand activity perhaps taking place at the basal domain of epithelial cells?

Finally, the data discussed in this review exemplify the coupling between somitogenesis and neurogenesis at multiple stages. Future research should address the implications of these early interactions to later morphogenesis and function of the neuromuscular and neuroskeletal systems.

Author Contributions: C.K. and N.K. conceived this article. C.K. wrote the manuscript. N.K. prepared the Figures. Both authors discussed and agreed on the text and approved the manuscript. All authors have read and agreed to the published version of the manuscript.

Funding: This study was supported by grants from the Israel Science Foundation (ISF \#209/18) and Ines Mandl Research Foundation (IMRF) to C.K.

Institutional Review Board Statement: Not applicable.

Informed Consent Statement: Not Applicable.

Acknowledgments: We thank all members of our laboratory for reading the manuscript.

Conflicts of Interest: The authors declare no conflict of interests. 


\section{References}

1. Pourquie, O. Vertebrate somitogenesis. Annu. Dev.Biol. 2001, 17, 311-350. [CrossRef]

2. Tzouanacou, E.; Wegener, A.; Wymeersch, F.J.; Wilson, V.; Nicolas, J.F. Redefining the Progression of Lineage Segregations during Mammalian Embryogenesis by Clonal Analysis. Dev. Cell 2009, 17, 365-376. [CrossRef] [PubMed]

3. Henrique, D.; Abranches, E.; Verrier, L.; Storey, K.G. Neuromesodermal progenitors and the making of the spinal cord. Development 2015, 142, 2864-2875. [CrossRef]

4. Steventon, B.; Martinez Arias, A. Evo-engineering and the cellular and molecular origins of the vertebrate spinal cord. Dev. Biol. 2017, 432, 3-13. [CrossRef]

5. $\quad$ Frith, T.J.R.; Granata, I.; Wind, M.; Stout, E.; Thompson, O.; Neumann, K.; Stavish, D.; Heath, P.R.; Ortmann, D.; Hackland, J.O.S.; et al. Human axial progenitors generate trunk neural crest cells in vitro. eLife 2018, 7. [CrossRef]

6. Hackland, J.O.S.; Shelar, P.B.; Sandhu, N.; Prasad, M.S.; Charney, R.M.; Gomez, G.A.; Frith, T.J.R.; García-Castro, M.I. FGF Modulates the Axial Identity of Trunk hPSC-Derived Neural Crest but Not the Cranial-Trunk Decision. Stem Cell Rep. 2019, 12, 920-933. [CrossRef]

7. Gomez, G.A.; Prasad, M.S.; Wong, M.; Charney, R.M.; Shelar, P.B.; Sandhu, N.; Hackland, J.O.S.; Hernandez, J.C.; Leung, A.W.; Garclá-Castro, M.I. WNT/ $\beta$-catenin modulates the axial identity of embryonic stem cell-derived human neural crest. Development 2019, 146. [CrossRef]

8. Lukoseviciute, M.; Mayes, S.; Sauka-Spengler, T. Neuromesodermal progenitor origin of trunk neural crest in vivo. BioRxiv 2021. [CrossRef]

9. Brent, A.; Tabin, C. Developmental regulation of somite derivatives: Muscle, cartilage and tendon. Curr. Opin. Genet. Dev. 2002, 12, 548. [CrossRef]

10. Christ, B.; Huang, R.; Scaal, M. Formation and differentiation of the avian sclerotome. Anat Embryol. 2004, 208, 333-350. Available online: http:/ / www.ncbi.nlm.nih.gov/entrez/query.fcgi?cmd=Retrieve\&db=PubMed\&dopt=Citation\&list_uids=15 309628 (accessed on 2 July 2021). [CrossRef] [PubMed]

11. Scaal, M.; Christ, B. Formation and differentiation of the avian dermomyotome. Anat Embryol. 2004, 208, 411-424. Available online: http:/ / www.ncbi.nlm.nih.gov / entrez/query.fcgi?cmd=Retrieve\&db=PubMed\&dopt=Citation\&list_uids=15338303 (accessed on 2 July 2021). [CrossRef]

12. Pourquie, O. Vertebrate somitogenesis: A novel paradigm for animal segmentation? Int. J. Dev. Biol. 2003, 47, 597-603. Available online: http:/ / www.ncbi.nlm.nih.gov / entrez/query.fcgi?cmd=Retrieve\&db=PubMed\&dopt=Citation\&list_uids=14 756335 (accessed on 2 July 2021).

13. Pourquie, O.; Fan, C.M.; Coltey, M.; Hirsinger, E.; Watanabe, Y.; Breant, C.; Francis-West, P.; Brickell, P.; Tessier-Lavigne, M.; Le Douarin, N.M. Lateral and axial signals involved in avian somite patterning: A role for BMP4. Cell 1996, 84, 461-471. [CrossRef]

14. Brand-Saberi, B.; Christ, B. Evolution and development of distinct cell lineages derived from somites. Curr. Top. Dev. Biol. 2002, 48, 1-42.

15. Kahane, N.; Cinnamon, Y.; Bachelet, I.; Kalcheim, C. The third wave of myotome colonization by mitotically competent progenitors: Regulating the balance between differentiation and proliferation during muscle development. Development 2001, 128, 2187-2198. [CrossRef] [PubMed]

16. Cinnamon, Y.; Kahane, N.; Kalcheim, C. Characterization of the early development of specific hypaxial muscles from the ventrolateral myotome. Development 1999, 126, 4305-4315. [CrossRef]

17. Gros, J.; Scaal, M.; Marcelle, C. A two-step mechanism for myotome formation in chick. Dev. Cell 2004, 6, 875-882. [CrossRef]

18. Huang, R.; Christ, B. Origin of the epaxial and hypaxial myotome in avian embryos. Anat. Embryol. 2000, 202, 369-374. [CrossRef] [PubMed]

19. Kahane, N.; Cinnamon, Y.; Kalcheim, C. The cellular mechanism by which the dermomyotome contributes to the second wave of myotome development. Development 1998, 125, 4259-4271. [CrossRef]

20. Ben-Yair, R.; Kalcheim, C. Lineage analysis of the avian dermomyotome sheet reveals the existence of single cells with both dermal and muscle progenitor fates. Development 2005, 132. [CrossRef] [PubMed]

21. Gros, J.; Manceau, M.; Thome, V.; Marcelle, C. A common somitic origin for embryonic muscle progenitors and satellite cells. Nature 2005, 435, 954-958. Available online: http:/ / www.ncbi.nlm.nih.gov/entrez/query.fcgi?cmd=Retrieve\&db=PubMed\& dopt=Citation\&list_uids=15843802 (accessed on 2 July 2021). [CrossRef] [PubMed]

22. Kassar-Duchosoy, L.; Giacone, E.; Gayraud-Morel, B.; Jory, A.; Gomes, D.; Tajbakhsh, S. Pax3/Pax7 mark a novel population of primitive myogenic cells during development. Genes Dev. 2005, 19, 1426-1431. [CrossRef]

23. Buckingham, M.; Relaix, F. PAX3 and PAX7 as upstream regulators of myogenesis. Semin. Cell Dev. Biol. 2015. [Internet]. Available online: http:/ / www.ncbi.nlm.nih.gov/pubmed/26424495 (accessed on 2 July 2021).

24. Ben-Yair, R.; Kahane, N.; Kalcheim, C. Coherent development of dermomyotome and dermis from the entire mediolateral extent of the dorsal somite. Development 2003, 130. [CrossRef]

25. Huang, R.J.; Zhi, Q.X.; Patel, K.; Wilting, J.; Christ, B. Dual origin and segmental organisation of the avian scapula. Development 2000, 127, 3789-3794. Available online: http:/ / www.ncbi.nlm.nih.gov/entrez/query.fcgi?cmd=Retrieve\&db=PubMed\&dopt= Citation\&list_uids=10934023 (accessed on 2 July 2021). [CrossRef]

26. Cinnamon, Y.; Ben-Yair, R.; Kalcheim, C. Differential effects of N-cadherin-mediated adhesion on the development of myotomal waves. Development 2006, 133. [CrossRef] 
27. Kahane, N.; Kalcheim, C. Identification of early postmitotic cells in distinct embryonic sites and their possible roles in morphogenesis. Cell Tissue Res. 1998, 294, 297-307. [CrossRef] [PubMed]

28. Kahane, N.; Cinnamon, Y.; Kalcheim, C. The roles of cell migration and myofiber intercalation in patterning formation of the postmitotic myotome. Development 2002, 129, 2675-2687. [CrossRef] [PubMed]

29. Halperin-Barlev, O.; Kalcheim, C. Sclerotome-derived slit1 drives directional migration and differentiation of robo2-expressing pioneer myoblasts. Development 2011, 138. [CrossRef]

30. Kalcheim, C.; Kahane, N.; Cinnamon, Y.; Ben-Yair, R. Mechanisms of lineage segregation in the avian dermomyotome. Anat. Embryol. 2006, 211. [CrossRef]

31. Saraga-Babic, M.; Krolo, M.; Sapunar, D.; Terzic, J.; Biocic, M. Differences in origin and fate between the cranial and caudal spinal cord during normal and disturbed human development. Acta Neuropathol. 1996, 91, 194-199. [CrossRef]

32. Colas, J.F.; Schoenwolf, G.C. Towards a cellular and molecular understanding of neurulation. Dev. Dyn. 2001, 221, 117-145. Available online: http:/ / www.ncbi.nlm.nih.gov / entrez/query.fcgi?cmd=Retrieve\&db=PubMed\&dopt=Citation\&list_uids=11 376482 (accessed on 2 July 2021). [CrossRef]

33. Shimokita, E.; Takahashi, Y. Secondary neurulation: Fate-mapping and gene manipulation of the neural tube in tail bud. Dev. Growth Differ. 2011, 53, 401-410. [CrossRef]

34. Gonzalez-Gobartt, E.; Blanco-Ameijeiras, J.; Usieto, S.; Allio, G.; Benazeraf, B.; Martí, E. Cell intercalation driven by SMAD3 underlies secondary neural tube formation. Dev. Cell 2021, 56, 1147.e6-1163.e6. [CrossRef] [PubMed]

35. Andrews, M.G.; Kong, J.; Novitch, B.G.; Butler, S.J. New perspectives on the mechanisms establishing the dorsal-ventral axis of the spinal cord. Curr. Top. Dev. Biol. 2019, 132, 417-450. Available online: http://www.ncbi.nlm.nih.gov/pubmed/30797516 (accessed on 2 July 2021). [CrossRef] [PubMed]

36. Helms, A.W.; Johnson, J.E. Specification of dorsal spinal cord interneurons. Curr. Opin. Neurobiol. 2003, 13, 42-49. Available online: http:/ / www.ncbi.nlm.nih.gov / entrez / query.fcgi?cmd=Retrieve\&db=PubMed\&dopt=Citation\&list_uids=12593981 (accessed on 2 July 2021). [CrossRef]

37. Le Dréau, G.; Martí, E. The multiple activities of BMPs during spinal cord development. Cell. Mol. Life Sci. 2013, 70, 4293-4305. [CrossRef]

38. Schoenwolf, G.C.; Smith, J.L. Mechanisms of neurulation: Traditional viewpoint and recent advances. Development 1990, 109, 243-270. [CrossRef] [PubMed]

39. Yamada, T.; Placzek, M.; Tanaka, H.; Dodd, J.; Jessell, T.M. Control of cell pattern in the developing nervous system: Polarizing activity of the floor plate and notochord. Cell 1991, 64, 635-647. [CrossRef]

40. Ward, L.; Pang, A.S.W.; Evans, S.E.; Stern, C.D. The role of the notochord in amniote vertebral column segmentation. Dev. Biol. 2018, 439, 3-18. [CrossRef]

41. Cohen, M.; Briscoe, J.; Blassberg, R. Morphogen interpretation: The transcriptional logic of neural tube patterning. Curr Opin Genet Dev 2013, 23， 423-428. Available online: http://www.ncbi.nlm.nih.gov/pubmed/23725799 (accessed on 2 July 2021). [CrossRef]

42. Dessaud, E.; Yang, L.L.; Hill, K.; Cox, B.; Ulloa, F.; Ribeiro, A.; Mynett, A.; Novitch, B.G.; Briscoe, J. Interpretation of the sonic hedgehog morphogen gradient by a temporal adaptation mechanism. Nature 2007, 450, 717-720. Available online: http:/ / www.ncbi.nlm.nih.gov/ pubmed/18046410 (accessed on 2 July 2021). [CrossRef]

43. Ribes, V.; Balaskas, N.; Sasai, N.; Cruz, C.; Dessaud, E.; Cayuso, J.; Tozer, S.; Yang, L.L.; Novitch, B.; Marti, E.; et al. Distinct Sonic Hedgehog signaling dynamics specify floor plate and ventral neuronal progenitors in the vertebrate neural tube. Genes Dev. 2010, 24, 1186-1200. Available online: http:/ / www.ncbi.nlm.nih.gov/entrez/query.fcgi?cmd=Retrieve\&db=PubMed\&dopt= Citation\&list_uids=20516201 (accessed on 2 July 2021). [CrossRef]

44. Ericson, J.; Briscoe, J.; Rashbass, P.; Van Heyningen, V.; Jessell, T.M. Graded sonic hedgehog signaling and the specification of cell fate in the ventral neural tube. Cold Spring Harb. Symp. Quant. Biol. 1997, 62, 451-466. [PubMed]

45. Gouti, M.; Metzis, V.; Briscoe, J. The route to spinal cord cell types: A tale of signals and switches. Trends Genet 2015, 31, 282-289. Available online: http:/ / www.ncbi.nlm.nih.gov/pubmed/25823696 (accessed on 2 July 2021). [CrossRef] [PubMed]

46. Jessell, T.M. Neuronal specification in the spinal cord: Inductive signals and transcriptional codes. Nat. Rev. Genet 2000, 1, 20-29. Available online: http:/ / www.ncbi.nlm.nih.gov/entrez/query.fcgi?cmd=Retrieve\&db=PubMed\&dopt=Citation\&list_uids=11 262869 (accessed on 2 July 2021). [CrossRef]

47. Briscoe, J.; Novitch, B.G. Regulatory pathways linking progenitor patterning, cell fates and neurogenesis in the ventral neural tube. Philos. Trans. R. Soc. B Biol. Sci. 2008, 363, 57-70. Available online: http://www.ncbi.nlm.nih.gov/pubmed/17282991 (accessed on 2 July 2021). [CrossRef] [PubMed]

48. Liem, K.F., Jr.; Tremml, G.; Jessell, T.M. A role for the roof plate and its resident TGFb-related proteins in neuronal patterning in the dorsal spinal cord. Cell 1997, 91, 127-138. [CrossRef]

49. Le Dréau, G.; Garcia-Campmany, L.; Angeles Rabadán, M.; Ferronha, T.; Tozer, S.; Briscoe, J.; Martí, E. Canonical BMP7 activity is required for the generation of discrete neuronal populations in the dorsal spinal cord. Development 2012, 139, 259-268. [CrossRef]

50. Hazen, V.M.; Phan, K.D.; Hudiburgh, S.; Butler, S.J. Inhibitory Smads differentially regulate cell fate specification and axon dynamics in the dorsal spinal cord. Dev. Biol. 2011, 356, 566-575. Available online: http://www.ncbi.nlm.nih.gov/pubmed/2171 8693 (accessed on 2 July 2021). [CrossRef]

51. Augsburger, A.; Schuchardt, A.; Hoskins, S.; Dodd, J.; Butler, S. Bmps as mediators of roof plate repulsion of commissural neurons. Neuron 1999, 24, 127-141. [CrossRef] 
52. Andrews, M.G.; Del Castillo, L.M.; Ochoa-Bolton, E.; Yamauchi, K.; Smogorzewski, J.; Butler, S.J. BMPs direct sensory interneuron identity in the developing spinal cord using signal-specific not morphogenic activities. eLife 2017, 6. Available online: http: / / www.ncbi.nlm.nih.gov/pubmed/28925352 (accessed on 2 July 2021). [CrossRef]

53. Tanabe, Y.; Jessell, T.M. Diversity and pattern in the developing spinal cord. Science 1996, 274, 1115-1123. [CrossRef]

54. Diez del Corral, R.; Olivera-Martinez, I.; Goriely, A.; Gale, E.; Maden, M.; Storey, K. Opposing FGF and retinoid pathways control ventral neural pattern, neuronal differentiation, and segmentation during body axis extension. Neuron 2003, 40, 65-79. Available online: http:/ / www.ncbi.nlm.nih.gov / entrez/query.fcgi?cmd=Retrieve\&db=PubMed\&dopt=Citation\&list_uids=14 527434 (accessed on 2 July 2021). [CrossRef]

55. Lai, H.C.; Seal, R.P.; Johnson, J.E. Making sense out of spinal cord somatosensory development. Development 2016, 143, 3434-3448. [CrossRef] [PubMed]

56. Le Douarin, N.M.; Kalcheim, C. The Neural Crest, 2nd ed.; Cambridge University Press: New York, NY, USA, 1999.

57. Piacentino, M.L.; Li, Y.; Bronner, M.E. Epithelial-to-mesenchymal transition and different migration strategies as viewed from the neural crest. Curr. Opin. Cell Biol. 2020, 66, 43-50. [CrossRef] [PubMed]

58. Nitzan, E.; Avraham, O.; Kahane, N.; Ofek, S.; Kumar, D.; Kalcheim, C. Dynamics of BMP and Hes1/Hairy1 signaling in the dorsal neural tube underlies the transition from neural crest to definitive roof plate. BMC Biol. 2016, 14, 23. [CrossRef] [PubMed]

59. Ofek, S.; Wiszniak, S.; Kagan, S.; Tondl, M.; Schwarz, Q.; Kalcheim, C. Notch signaling is a critical initiator of roof plate formation as revealed by the use of RNA profiling of the dorsal neural tube. BMC Biol. 2021, 19. [CrossRef] [PubMed]

60. Chizhikov, V.V.; Millen, K.J. Mechanisms of roof plate formation in the vertebrate CNS. Nat. Rev. Neurosci. 2004, 5, 808-812. Available online: http:/ / www.ncbi.nlm.nih.gov / entrez / query.fcgi?cmd=Retrieve\&db=PubMed\&dopt=Citation\&list_uids=15 378040 (accessed on 2 July 2021). [CrossRef] [PubMed]

61. Guillot, C.; Michaut, A.; Rabe, B.; Pourquié, O. Dynamics of primitive streak regression controls the fate of neuro-mesodermal progenitors in the chicken embryo. eLife 2021, 1-36. [CrossRef]

62. Goto, H.; Kimmey, S.C.; Row, R.H.; Matus, D.Q.; Martin, B.L. FGF and canonical Wnt signaling cooperate to induce paraxial mesoderm from tailbud neuromesodermal progenitors through regulation of a two-step epithelial to mesenchymal transition. Development 2017, 144, 1412-1421. [CrossRef]

63. Kinney, B.A.; Al Anber, A.; Row, R.H.; Tseng, Y.J.; Weidmann, M.D.; Knaut, H.; Martin, B.L. Sox2 and Canonical Wnt Signaling Interact to Activate a Developmental Checkpoint Coordinating Morphogenesis with Mesoderm Fate Acquisition. Cell Rep. 2020, 33, 108311. [CrossRef] [PubMed]

64. Yang, J.; Antin, P.; Berx, G.; Blanpain, C.; Brabletz, T.; Bronner, M.; Campbell, K.; Cano, A.; Casanova, J.; Christofori, G.; et al. Guidelines and definitions for research on epithelial-mesenchymal transition. Nat. Rev. Mol. Cell Biol. 2020, 21, 341-352. [CrossRef] [PubMed]

65. Chapman, D.L.; Papaioannou, V.E. Three neural tubes in mouse embryos with mutations in T-box gene Tbx6. Nature 1998, 391, 695-697. [CrossRef] [PubMed]

66. Yamaguchi, T.P.; Takada, S.; Yoshikawa, Y.; Wu, N.Y.; McMahon, A.P. T (Brachyury) is a direct target of Wnt3a during paraxial mesoderm specification. Genes Dev. 1999, 13, 3185-3190. [CrossRef] [PubMed]

67. Yoshikawa, Y.; Fujimori, T.; McMahon, A.P.; Takada, S. Evidence that absence of Wnt-3a signaling promotes neuralization instead of paraxial mesoderm development in the mouse. Dev.Biol. 1997, 183, 234-242. [CrossRef]

68. Ciruna, B.G.; Schwartz, L.; Harpal, K.; Yamaguchi, T.P.; Rossant, J. Chimeric analysis of fibroblast growth factor receptor-1 (Fgfr1) function: A role for FGFR1 in morphogenetic movement through the primitive streak. Development 1997, 124, $2829-2841$. Available online: http:/ / www.ncbi.nlm.nih.gov / entrez/query.fcgi?cmd=Retrieve\&db=PubMed\&dopt=Citation\&list_uids=92 26454 (accessed on 2 July 2021). [CrossRef] [PubMed]

69. Garriock, R.J.; Chalamalasetty, R.B.; Kennedy, M.W.; Canizales, L.C.; Lewandoski, M.; Yamaguchi, T.P. Lineage tracing of neuromesodermal progenitors reveals novel wnt-dependent roles in trunk progenitor cell maintenance and differentiation. Development 2015, 142, 1628-1638. [CrossRef]

70. Wymeersch, F.J.; Huang, Y.; Blin, G.; Cambray, N.; Wilkie, R.; Wong, F.C.K.; Wilson, V. Position-dependent plasticity of distinct progenitor types in the primitive streak. eLife 2016, 5. [CrossRef]

71. Cunningham, T.J.; Brade, T.; Sandell, L.L.; Lewandoski, M.; Trainor, P.A.; Colas, A.; Mercola, M.; Duester, G. Retinoic acid activity in undifferentiated neural progenitors is sufficient to fulfill its role in restricting Fgf8 expression for somitogenesis. PLoS ONE 2015, 10, 1-15. [CrossRef]

72. Gouti, M.; Delile, J.; Stamataki, D.; Wymeersch, F.J.; Huang, Y.; Kleinjung, J.; Wilson, V.; Briscoe, J. A Gene Regulatory Network Balances Neural and Mesoderm Specification during Vertebrate Trunk Development. Dev. Cell 2017, 41, 243.e7-261.e7. [CrossRef]

73. Appel, B.; Korzh, V.; Glasgow, E.; Thor, S.; Edlund, T.; Dawid, I.B.; Eisen, J.S. Motoneuron fate specification revealed by patterned LIM homeobox gene expression in embryonic zebrafish. Development 1995, 121, 4117-4125. [CrossRef]

74. Eisen, J.S. Determination of primary motoneuron identity in developing zebrafish embryos. Science 1991, $252,569-572$. [CrossRef] [PubMed]

75. Bisgrove, B.W.; Raible, D.W.; Walter, V.; Eisen, J.S.; Grunwald, D.J. Expression of c-ret in the zebrafish embryo: Potential roles in motoneuronal development. J. Neurobiol. 1997, 33, 749-768. [CrossRef]

76. Eisen, J.S.; Pike, S.H. The spt-1 mutation alters segmental arrangement and axonal development of identified neurons in the spinal cord of the embryonic zebrafish. Neuron 1991, 6, 767-776. [CrossRef] 
77. Lewis, K.E.; Eisen, J.S. Paraxial mesoderm specifies zebrafish primary motoneuron subtype identity. Development 2004, 131, 891-902. [CrossRef]

78. Inoue, A.; Takahashi, M.; Hatta, K.; Hotta, Y.; Okamoto, H. Developmental regulation of Islet-1 mRNA expression during neuronal differentiation in embryonic zebrafish. Dev. Dyn. 1994, 199, 1-11. [CrossRef]

79. Tokumoto, M.; Gong, Z.Y.; Tsubokawa, T.; Hew, C.L.; Uyemura, K.; Hotta, Y.; Okamoto, H. Molecular heterogeneity among primary motoneurons and within myotomes revealed by the differential mRNA expression of novel islet- 1 homologs in embryonic zebrafish. Dev.Biol. 1995, 171, 578-589. [CrossRef] [PubMed]

80. Kimmel, C.B.; Miller, C.T.; Kruze, G.; Ullmann, B.; Bremiller, R.A.; Larison, K.D.; Snyder, H.C. The shaping of pharyngeal cartilages during early development of the zebrafish. Dev. Biol. 1998, 203, 245-263. [CrossRef]

81. Roy, M.N.; Prince, V.E.; Ho, R.K. Heat shock produces periodic somitic disturbances in the zebrafish embryo. Mech. Dev. 1999, 85, 27-34. [CrossRef]

82. Diez del Corral, R.; Breitkreuz, D.; Storey, K.G. Onset of neuronal differentiation is regulated by paraxial mesoderm and requires attenuation of FGF signalling. Development 2002, 129, 1681-1691. [CrossRef]

83. Veenvliet, J.V.; Bolondi, A.; Kretzmer, H.; Haut, L.; Scholze-Wittler, M.; Schifferl, D.; Koch, F.; Guignard, L.; Kumar, A.S.; Pustet, M.; et al. Modeling mammalian trunk development in a dish. Science 2020, 370, eaba4937. Available online: https: / / pubmed.ncbi.nlm.nih.gov/33303587/ (accessed on 2 July 2021). [CrossRef] [PubMed]

84. Sosic, D.; Brand-Saberi, B.; Schmidt, C.; Christ, B.; Olson, E.N. Regulation of paraxis expression and somite formation by ectodermand neural tube-derived signals. Dev.Biol. 1997, 185, 229-243. [CrossRef]

85. Basch, M.L.; Bronner-Fraser, M. Neural crest inducing signals. Adv. Exp. Med. Biol. 2006, 589, 24-31. Available online: http:/ / www.ncbi.nlm.nih.gov/entrez/query.fcgi?cmd=Retrieve\&db=PubMed\&dopt=Citation\&list_uids=17076273 (accessed on 2 July 2021). [PubMed]

86. Basch, M.L.; Bronner-Fraser, M.; Garcia-Castro, M.I. Specification of the neural crest occurs during gastrulation and requires Pax7. Nature 2006, 441, 218-222. Available online: http:/ / www.ncbi.nlm.nih.gov/entrez/query.fcgi?cmd=Retrieve\&db=PubMed\& dopt=Citation\&list_uids $=16688176$ (accessed on 2 July 2021). [CrossRef]

87. Stuhlmiller, T.J.; Garcia-Castro, M.I. Current perspectives of the signaling pathways directing neural crest induction. Cell Mol Life Sci. 2012. Available online: http:/ / www.ncbi.nlm.nih.gov/entrez/query.fcgi?cmd=Retrieve\&db=PubMed\&dopt= Citation\&list_uids=22547091 (accessed on 2 July 2021). [CrossRef]

88. Steventon, B.; Araya, C.; Linker, C.; Kuriyama, S.; Mayor, R. Differential requirements of BMP and Wnt signalling during gastrulation and neurulation define two steps in neural crest induction. Development 2009, 136, 771-779. Available online: http:/ /www. ncbi.nlm.nih.gov/entrez/query.fcgi?cmd=Retrieve\&db=PubMed\&dopt=Citation\&list_uids=19176585 (accessed on 2 July 2021). [CrossRef] [PubMed]

89. Monsoro-Burq, A.H.; Fletcher, R.B.; Harland, R.M. Neural crest induction by paraxial mesoderm in Xenopus embryos requires FGF signals. Development 2003, 130, 3111-3124. Available online: http://www.ncbi.nlm.nih.gov/entrez/query.fcgi?cmd= Retrieve\&db=PubMed\&dopt=Citation\&list_uids=12783784 (accessed on 2 July 2021). [CrossRef]

90. Bonstein, L.; Elias, S.; Frank, D. Paraxial-fated mesoderm is required for neural crest induction in Xenopus embryos. Dev. Biol. 1998, 193, 156-168. [CrossRef]

91. Bonano, M.; Tribulo, C.; De Calisto, J.; Marchant, L.; Sanchez, S.S.; Mayor, R.; Aybar, M.J. A new role for the Endothelin1/Endothelin-A receptor signaling during early neural crest specification. Dev. Biol. 2008, 323, 114-129. Available online: http:/ / www.ncbi.nlm.nih.gov / entrez/query.fcgi? cmd=Retrieve\&db=PubMed\&dopt=Citation\&list_uids=18775422 (accessed on 2 July 2021). [CrossRef]

92. Mayor, R.; Morgan, R.; Sargent, M.G. Induction of the prospective neural crest of xenopus. Development 1995, 121, 767-777. [CrossRef]

93. Hong, C.S.; Park, B.Y.; Saint-Jeannet, J.P. Fgf8a induces neural crest indirectly through the activation of Wnt8 in the paraxial mesoderm. Development 2008, 135, 3903-3910. Available online: http:/ / www.ncbi.nlm.nih.gov/entrez/query.fcgi?cmd=Retrieve\& $\mathrm{db}=$ PubMed\&dopt=Citation\&list_uids=18997112 (accessed on 2 July 2021). [CrossRef]

94. Selleck, M.A.J.; Bronner-Fraser, M. Origins of the avian neural crest: The role of neural plate-epidermal interactions. Development 1995, 121, 525-538. Available online: http:/ /www.ncbi.nlm.nih.gov/entrez/query.fcgi?cmd=Retrieve\&db=PubMed\&dopt= Citation\&list_uids $=7768190$ (accessed on 2 July 2021). [CrossRef]

95. Loring, J.F.; Erickson, C.A. Neural crest cell migratory pathways in the trunk of the chick embryo. Dev. Biol. 1987, 121, 220-236. [CrossRef]

96. Teillet, M.-A.; Kalcheim, C.; Le Douarin, N.M. Formation of the dorsal root ganglia in the avian embryo: Segmental origin and migratory behavior of neural crest progenitor cells. Dev. Biol. 1987, 120. [CrossRef]

97. Kalcheim, C.; Teillet, M.-A. Consequences of somite manipulation on the pattern of dorsal root ganglion development. Development 1989, 106, 85-93. [CrossRef]

98. Sela-Donenfeld, D.; Kalcheim, C. Regulation of the onset of neural crest migration by coordinated activity of BMP4 and Noggin in the dorsal neural tube. Development 1999, 126, 4749-4762. [CrossRef] [PubMed]

99. Burstyn-Cohen, T.; Stanleigh, J.; Sela-Donenfeld, D.; Kalcheim, C. Canonical Wnt activity regulates trunk neural crest delamination linking BMP/noggin signaling with G1/S transition. Development 2004, 131, 5327-5339. [CrossRef] [PubMed]

100. Sela-Donenfeld, D.; Kalcheim, C. Inhibition of noggin expression in the dorsal neural tube by somitogenesis: A mechanism for coordinating the timing of neural crest emigration. Development 2000, 127, 4845-4854. [CrossRef] 
101. Martínez-Morales, P.L.; del Corral, R.D.; Olivera-Martínez, I.; Quiroga, A.C.; Das, R.M.; Barbas, J.A.; Storey, K.G.; Morales, A.V. FGF and retinoic acid activity gradients control the timing of neural crest cell emigration in the trunk. J. Cell Biol. 2011, 194, 489-503. [CrossRef]

102. Goldstein, R.S.; Kalcheim, C. Normal segmentation and size of the primary sympathetic ganglia depend upon the alternation of rostrocaudal properties of the somites. Development 1991, 112, 327-334. [CrossRef]

103. Keynes, R.; Cook, G.; Davies, J.; Lumsden, A.; Norris, W.; Stern, C. Segmentation and the development of the vertebrate nervous system. J. Physiol. 1990, 84, 27-32. Available online: http://www.ncbi.nlm.nih.gov/entrez/query.fcgi? cmd=Retrieve\&db= PubMed\&dopt=Citation\&list_uids=2193147 (accessed on 2 July 2021).

104. Keynes, R.; Stern, C.D. Segmentation in the vertebrate nervous system. Nature 1984, 310, 786-789. [CrossRef]

105. Kalcheim, C. Mechanisms of Early Neural crest Development: From Cell Specification to Migration; Elsevier: Amsterdam, The Netherlands, 2000; Volume 200.

106. Goldstein, R.S.; Kalcheim, C. Determination of epithelial half-somites in skeletal morphogenesis. Development 1992, 116. [CrossRef]

107. Bruggeman, B.J.; Maier, J.A.; Mohiuddin, Y.S.; Powers, R.; Lo, Y.; Guimaraes-Camboa, N.; Evans, S.M.; Harfe, B.D. Avian intervertebral disc arises from rostral sclerotome and lacks a nucleus pulposus: Implications for evolution of the vertebrate disc. Dev. Dyn. 2012, 241, 675-683. Available online: http://www.ncbi.nlm.nih.gov/entrez/query.fcgi?cmd=Retrieve\&db=PubMed\& dopt=Citation\&list_uids=22354863 (accessed on 2 July 2021). [CrossRef]

108. Kuriyama, S.; Mayor, R. Molecular analysis of neural crest migration. Philos. Trans. R. Soc. L. B Biol. Sci. 2008, 363, 1349-1362. Available online: http:/ / www.ncbi.nlm.nih.gov / entrez / query.fcgi?cmd=Retrieve\&db=PubMed\&dopt=Citation\&list_uids=18 198151 (accessed on 2 July 2021). [CrossRef] [PubMed]

109. Krull, C.E. Segmental organization of neural crest migration. Mech. Dev. 2001, 105, 37-45. Available online: http:/ / www.ncbi.nlm nih.gov/entrez/query.fcgi?cmd=Retrieve\&db=PubMed\&dopt=Citation\&list_uids=11429280 (accessed on 2 July 2021). [CrossRef]

110. Gammill, L.S.; Gonzalez, C.; Gu, C.; Bronner-Fraser, M. Guidance of trunk neural crest migration requires neuropilin 2/semaphorin 3F signaling. Development 2006, 133, 99-106. Available online: http:/ / www.ncbi.nlm.nih.gov/entrez/query.fcgi? cmd=Retrieve\&db=PubMed\&dopt=Citation\&list_uids=16319111 (accessed on 2 July 2021). [CrossRef] [PubMed]

111. Debby-Brafman, A.; Burstyn-Cohen, T.; Klar, A.; Kalcheim, C. F-spondin is expressed in somite regions avoided by neural crest cells and mediates the inhibition of distinct somitic domains to neural crest migration. Neuron 1999, 22, 475-488. [CrossRef]

112. Roffers-Agarwal, J.; Gammill, L.S. Neuropilin receptors guide distinct phases of sensory and motor neuronal segmentation. Development 2009, 136, 1879-1888. Available online: http://www.ncbi.nlm.nih.gov/entrez/query.fcgi?cmd=Retrieve\&db= PubMed\&dopt=Citation\&list_uids=19403658 (accessed on 2 July 2021). [CrossRef] [PubMed]

113. Schwarz, Q.; Maden, C.H.; Davidson, K.; Ruhrberg, C. Neuropilin-mediated neural crest cell guidance is essential to organise sensory neurons into segmented dorsal root ganglia. Development 2009, 136, 1785-1789. Available online: http:/ /www.ncbi.nlm. nih.gov / entrez/query.fcgi?cmd=Retrieve\&db=PubMed\&dopt=Citation\&list_uids=19386662 (accessed on 2 July 2021). [CrossRef]

114. Krull, C.E.; Lansford, R.; Gale, N.W.; Collazo, A.; Marcelle, C.; Yancopoulos, G.D.; Fraser, S.E.; Bronner Fraser, M.; Bronner-Fraser, M. Interactions of Eph-related receptors and ligands confer rostrocaudal pattern to trunk neural crest migration. Curr. Biol. 1997, 7, 571-580. [CrossRef]

115. Erickson, C.A.; Duong, T.D.; Tosney, K.W. Descriptive and experimental analysis of the dispersion of neural crest cells along the dorsolateral path and their entry into ectoderm in the chick embryo. Dev. Biol. 1992, 151, 251-272. [CrossRef]

116. Nitzan, E.; Pfaltzgraff, E.R.; Labosky, P.A.; Kalcheim, C. Neural crest and Schwann cell progenitor-derived melanocytes are two spatially segregated populations similarly regulated by Foxd3. Proc. Natl. Acad. Sci. USA 2013, 110. [CrossRef]

117. Adameyko, I.; Lallemend, F.; Aquino, J.B.; Pereira, J.A.; Topilko, P.; Muller, T.; Fritz, N.; Beljajeva, A.; Mochii, M.; Liste, I.; et al. Schwann cell precursors from nerve innervation are a cellular origin of melanocytes in skin. Cell 2009, 139, 366-379. Available online: http:/ / www.ncbi.nlm.nih.gov / entrez / query.fcgi?cmd=Retrieve\&db=PubMed\&dopt=Citation\&list_uids=19 837037 (accessed on 2 July 2021). [CrossRef]

118. Jia, L.; Cheng, L.; Raper, J. Slit/Robo signaling is necessary to confine early neural crest cells to the ventral migratory pathway in the trunk. Dev. Biol. 2005, 282, 411-421. Available online: http://www.ncbi.nlm.nih.gov/entrez/query.fcgi? cmd=Retrieve\&db= PubMed\&dopt=Citation\&list_uids=15950606 (accessed on 2 July 2021). [CrossRef] [PubMed]

119. Oakley, R.A.; Lasky, C.J.; Erickson, C.A.; Tosney, K.W. Glycoconjugates mark a transient barrier to neural crest migration in the chicken embryo. Development 1994, 120, 103-114. [CrossRef]

120. Oakley, R.A.; Tosney, K.W. Peanut agglutinin and chondroitin-6-sulfate are molecular markers for tissues that act as barriers to axon advance in the avian embryo. Dev. Biol. 1991, 147, 187-206. [CrossRef]

121. Santiago, A.; Erickson, C.A. Ephrin-B ligands play a dual role in the control of neural crest cell migration. Development 2002, 129, 3621-3632. [CrossRef] [PubMed]

122. Harris, M.L.; Hall, R.; Erickson, C.A. Directing pathfinding along the dorsolateral path-The role of EDNRB2 and EphB2 in overcoming inhibition. Development 2008, 135, 4113-4122. Available online: http:/ / www.ncbi.nlm.nih.gov/entrez/query.fcgi? $\mathrm{cmd}=$ Retrieve\&db=PubMed\&dopt=Citation\&list_uids=19004859 (accessed on 2 July 2021). [CrossRef]

123. Lecoin, L.; Sakurai, T.; Ngo, M.T.; Abe, Y.; Yanagisawa, M.; Le Douarin, N.M. Cloning and characterization of a novel endothelin receptor subtype in the avian class. Proc. Natl. Acad. Sci. USA 1998, 95, 3024-3029. [CrossRef] [PubMed] 
124. Nataf, V.; Amemiya, A.; Yanagisawa, M.; Le Douarin, N.M. The expression pattern of endothelin 3 in the avian embryo. Mech. Dev. 1998, 73, 217-220. Available online: http://www.ncbi.nlm.nih.gov/entrez/query.fcgi?cmd=Retrieve\&db=PubMed\& dopt=Citation\&list_uids=9622636 (accessed on 2 July 2021). [CrossRef]

125. Krispin, S.; Nitzan, E.; Kassem, Y.; Kalcheim, C. Evidence for a dynamic spatiotemporal fate map and early fate restrictions of premigratory avian neural crest. Development 2010, 137, 585-595. [CrossRef]

126. Nagy, N.; Goldstein, A.M. Endothelin-3 regulates neural crest cell proliferation and differentiation in the hindgut enteric nervous system. Dev. Biol. 2006, 293, 203-217. Available online: http:/ /www.ncbi.nlm.nih.gov/entrez/query.fcgi?cmd=Retrieve\&db= PubMed\&dopt=Citation\&list_uids=16519884 (accessed on 2 July 2021). [CrossRef]

127. Noden, D.M.; Trainor, P.A. Relations and interactions between cranial mesoderm and neural crest populations. J. Anat. 2005, 207, 575-601. Available online: http:/ / www.ncbi.nlm.nih.gov/entrez/query.fcgi?cmd=Retrieve\&db=PubMed\&dopt= Citation\&list_uids=16313393 (accessed on 2 July 2021). [CrossRef]

128. Couly, G.F.; Coltey, P.M.; Le Douarin, N.M. The developmental fate of the cephalic mesoderm in quail-chick chimeras. Development 1992, 114, 1-15. [CrossRef]

129. Cerny, R.; Meulemans, D.; Berger, J.; Wilsch-Brauninger, M.; Kurth, T.; Bronner-Fraser, M.; Epperlein, H.H. Combined intrinsic and extrinsic influences pattern cranial neural crest migration and pharyngeal arch morphogenesis in axolotl. Dev. Biol. 2004, 266, 252-269. Available online: http://www.ncbi.nlm.nih.gov/entrez/query.fcgi? cmd=Retrieve\&db=PubMed\&dopt= Citation\&list_uids=14738875 (accessed on 2 July 2021). [CrossRef] [PubMed]

130. Köntges, G.; Lumsden, A. Rhombencephalic neural crest segmentation is preserved throughout craniofacial ontogeny. Development 1996, 122, 3229-3242. [CrossRef]

131. Noden, D.M. The embryonic origins of avian cephalic and cervical muscles and associated connective tissues. Am. J. Anat. 1983, 168, 257-276. [CrossRef]

132. Grammatopoulos, G.A.; Bell, E.; Toole, L.; Lumsden, A.; Tucker, A.S. Homeotic transformation of branchial arch identity after Hoxa2 overexpression. Development 2000, 127, 5355-5365. Available online: http:/ /www.ncbi.nlm.nih.gov/entrez/query.fcgi? $\mathrm{cmd}=$ Retrieve\&db=PubMed\&dopt=Citation\&list_uids=11076757 (accessed on 2 July 2021). [CrossRef] [PubMed]

133. Schilling, T.F.; Kimmel, C.B. Musculoskeletal patterning in the pharyngeal segments of the zebrafish embryo. Development 1997, 124, 2945-2960. Available online: http:/ / www.ncbi.nlm.nih.gov/entrez/query.fcgi?cmd=Retrieve\&db=PubMed\&dopt= Citation\&list_uids=9247337 (accessed on 2 July 2021). [CrossRef] [PubMed]

134. Grenier, J.; Teillet, M.A.; Grifone, R.; Kelly, R.G.; Duprez, D. Relationship between neural crest cells and cranial mesoderm during head muscle development. PLOS ONE 2009, 4, e4381. Available online: http:/ / www.ncbi.nlm.nih.gov/entrez/query.fcgi?cmd= Retrieve\&db=PubMed\&dopt=Citation\&list_uids=19198652 (accessed on 2 July 2021). [CrossRef]

135. Rinon, A.; Lazar, S.; Marshall, H.; Buchmann-Moller, S.; Neufeld, A.; Elhanany-Tamir, H.; Taketo, M.M.; Sommer, L.; Krumlauf, R.; Tzahor, E. Cranial neural crest cells regulate head muscle patterning and differentiation during vertebrate embryogenesis. Development 2007, 134, 3065-3075. Available online: http://www.ncbi.nlm.nih.gov/entrez/query.fcgi?cmd=Retrieve\&db= PubMed\&dopt=Citation\&list_uids=17652354 (accessed on 2 July 2021). [CrossRef]

136. Sela-Donenfeld, D.; Kalcheim, C. Localized BMP4-noggin interactions generate the dynamic patterning of noggin expression in somites. Dev. Biol. 2002, 246. [CrossRef]

137. Brill, G.; Kahane, N.; Carmeli, C.; Von Schack, D.; Barde, Y.-A.; Kalcheim, C. Epithelial-mesenchymal conversion of dermatome progenitors requires neural tube-derived signals: Characterization of the role of Neurotrophin-3. Development 1995, 121. [CrossRef]

138. Spence, M.S.; Yip, J.; Erickson, C.A. The dorsal neural tube organizes the dermamyotome and induces axial myocytes in the avian embryo. Development 1996, 122, 231-241. [CrossRef]

139. Olivera-Martinez, I.; Thelu, J.; Teillet, M.; Dhouailly, D. Dorsal dermis development depends on a signal from the dorsal neural tube, which can be substituted by Wnt-1. Mech. Dev. 2001, 100, 233-244. [CrossRef]

140. Capdevila, J.; Tabin, C.; Johnson, R.L. Control of dorsoventral somite patterning by Wnt-1 and b-catenin. Dev. Biol. 1998, 193, 182-194. [CrossRef] [PubMed]

141. Ikeya, M.; Takada, S. Wnt signaling from the dorsal neural tube is required for the formation of the medial dermomyotome. Development 1998, 125, 4969-4976. [CrossRef] [PubMed]

142. Schmidt, M.; Tanaka, M.; Münsterberg, A. Expression of b-catenin in the developing chick myotome is regulated by myogenic signals. Development 2000, 127, 4105-4113. [CrossRef]

143. Marcelle, C.; Stark, M.R.; Bronner-Fraser, M. Coordinate actions of BMPs, Wnts, Shh and noggin mediate patterning of the dorsal somite. Development 1997, 124, 3955-3963. [CrossRef] [PubMed]

144. Rios, A.C.; Serralbo, O.; Salgado, D.; Marcelle, C. Neural crest regulates myogenesis through the transient activation of NOTCH. Nature 2011, 473, 532-535. Available online: http:/ / www.ncbi.nlm.nih.gov/entrez/query.fcgi?cmd=Retrieve\&db=PubMed\& dopt=Citation\&list_uids=21572437 (accessed on 2 July 2021). [CrossRef] [PubMed]

145. Van Ho, S.; Brohl, D.; Aurade, F.; Rattenbach, R.; Relaix, F. Neural crest cell lineage restricts skeletal muscle progenitor cell differentiation through Neuregulin-ErbB3 signaling. Dev. Cell 2011, 21, 273-287. [PubMed]

146. Kalcheim, C. Regulation of Trunk Myogenesis by the Neural Crest: A New Facet of Neural Crest-Somite Interactions. Dev. Cell 2011, 21. [CrossRef] [PubMed] 
147. Borycki, A.G.; Mendham, L.; Emerson, C.P., Jr. Control of somite patterning by Sonic hedgehog and its downstream signal response genes. Development 1998, 125, 777-790. Available online: http://www.ncbi.nlm.nih.gov/entrez/query.fcgi?cmd= Retrieve\&db=PubMed\&dopt=Citation\&list_uids=9435297 (accessed on 2 July 2021). [CrossRef] [PubMed]

148. Briscoe, J. Making a grade: Sonic Hedgehog signalling and the control of neural cell fate. EMBO J. 2009, 28, 457-465. Available online: http:/ / www.ncbi.nlm.nih.gov / entrez/query.fcgi? cmd=Retrieve\&db=PubMed\&dopt=Citation\&list_uids=19197245 (accessed on 2 July 2021). [CrossRef]

149. Cairns, D.M.; Sato, M.E.; Lee, P.G.; Lassar, A.B.; Zeng, L. A gradient of Shh establishes mutually repressing somitic cell fates induced by Nkx3.2 and Pax3. Dev. Biol. 2008, 323, 152-165. Available online: http://www.ncbi.nlm.nih.gov/entrez/query.fcgi? $\mathrm{cmd}=$ Retrieve\&db=PubMed\&dopt=Citation\&list_uids=18796301 (accessed on 2 July 2021). [CrossRef]

150. Ericson, J.; Rashbass, P.; Schedl, A.; Brenner-Morton, S.; Kawakami, A.; Van Heyningen, V.; Jessell, T.M.; Briscoe, J. Pax6 controls progenitor cell identity and neuronal fate in response to graded shh signaling. Cell 1997, 90, 169-180. [CrossRef]

151. Gustafsson, M.K.; Pan, H.; Pinney, D.F.; Liu, Y.L.; Lewandowski, A.; Epstein, D.J.; Emerson, C.P., Jr. Myf5 is a direct target of long-range Shh signaling and Gli regulation for muscle specification. Genes Dev. 2002, 16, 114-126. [CrossRef]

152. Goodrich, L.V.; Milenkovic, L.; Higgins, K.M.; Scott, M.P. Altered neural cell fates and medulloblastoma in mouse patched mutants. Science 1997, 277, 1109-1113. [CrossRef]

153. Hidalgo, A.; Ingham, P. Cell patterning in the Drosophila segment: Spatial regulation of the segment polarity gene patched. Development 1990, 110, 291-301. Available online: http:/ /www.ncbi.nlm.nih.gov/pubmed/2081466 (accessed on 2 July 2021). [CrossRef]

154. Van den Heuvel, M.; Ingham, P.W. smoothened encodes a receptor-like serpentine protein required for hedgehog signalling. Nature 1996, 382, 547-551. Available online: http:/ /www.ncbi.nlm.nih.gov/pubmed/8700230 (accessed on 2 July 2021). [CrossRef]

155. Caspary, T.; Larkins, C.E.; Anderson, K.V. The graded response to Sonic Hedgehog depends on cilia architecture. Dev. Cell 2007, 12, 767-778. Available online: http:/ / www.ncbi.nlm.nih.gov/pubmed/17488627 (accessed on 2 July 2021). [CrossRef]

156. Rohatgi, R.; Milenkovic, L.; Scott, M.P. Patched1 regulates hedgehog signaling at the primary cilium. Science 2007, 317, 372-376. Available online: http://www.ncbi.nlm.nih.gov/pubmed/17641202 (accessed on 2 July 2021). [CrossRef]

157. Milenkovic, L.; Scott, M.P.; Rohatgi, R. Lateral transport of Smoothened from the plasma membrane to the membrane of the cilium. J. Cell Biol. 2009, 187, 365-374. Available online: http://www.ncbi.nlm.nih.gov/pubmed/19948480 (accessed on 2 July 2021). [CrossRef]

158. Rohatgi, R.; Milenkovic, L.; Corcoran, R.B.; Scott, M.P. Hedgehog signal transduction by Smoothened: Pharmacologic evidence for a 2-step activation process. Proc. Natl. Acad. Sci. USA 2009, 106, 3196-3201. Available online: http:/ /www.ncbi.nlm.nih.gov/ pubmed/19218434 (accessed on 2 July 2021). [CrossRef] [PubMed]

159. Briscoe, J.; Therond, P.P. The mechanisms of Hedgehog signalling and its roles in development and disease. Nat. Rev. Mol. Cell Biol. 2013, 14, 416-429. Available online: http:/ / www.ncbi.nlm.nih.gov/ pubmed/23719536 (accessed on 2 July 2021). [CrossRef] [PubMed]

160. Ribes, V.; Briscoe, J. Establishing and interpreting graded Sonic Hedgehog signaling during vertebrate neural tube patterning: The role of negative feedback. Cold Spring Harb. Perspect. Biol. 2009, 1, 1-16. Available online: http:/ /www.ncbi.nlm.nih.gov/ entrez/query.fcgi?cmd=Retrieve\&db=PubMed\&dopt=Citation\&list_uids=20066087 (accessed on 2 July 2021). [CrossRef]

161. Chuang, P.T.; McMahon, A.P. Vertebrate hedgehog signalling modulated by induction of a hedgehog- binding protein. Nature 1999, 397, 617-621. [CrossRef]

162. Ingham, P.W.; McMahon, A.P. Hedgehog signaling in animal development: Paradigms and principles. Genes Dev. 2001, 15, 3059-3087. [CrossRef] [PubMed]

163. Dhoot, G.K.; Gustafsson, M.K.; Ai, X.; Sun, W.; Standiford, D.M.; Emerson, C.P., Jr. Regulation of Wnt signaling and embryo patterning by an extracellular sulfatase. Science 2001, 293, 1663-1666. [CrossRef]

164. Izzi, L.; Levesque, M.; Morin, S.; Laniel, D.; Wilkes, B.C.; Mille, F.; Krauss, R.S.; McMahon, A.P.; Allen, B.L.; Charron, F. Boc and Gas1 each form distinct Shh receptor complexes with Ptch1 and are required for Shh-mediated cell proliferation. Dev. Cell 2011, 20, 788-801. Available online: http:/ / www.ncbi.nlm.nih.gov / entrez/query.fcgi? cmd=Retrieve\&db=PubMed\&dopt=Citation\& list_uids=21664577 (accessed on 2 July 2021). [CrossRef]

165. Allen, B.L.; Song, J.Y.; Izzi, L.; Althaus, I.W.; Kang, J.S.; Charron, F.; Krauss, R.S.; McMahon, A.P. Overlapping roles and collective requirement for the coreceptors GAS1, CDO, and BOC in SHH pathway function. Dev. Cell 2011, 20, 775-787. Available online: http:/ / www.ncbi.nlm.nih.gov / entrez / query.fcgi?cmd=Retrieve\&db=PubMed\&dopt=Citation\&list_uids=21 664576 (accessed on 2 July 2021). [CrossRef] [PubMed]

166. Kahane, N.; Ribes, V.; Kicheva, A.; Briscoe, J.; Kalcheim, C. The transition from differentiation to growth during dermomyotomederived myogenesis depends on temporally restricted hedgehog signaling. Development 2013, 140. [CrossRef]

167. Briscoe, J.; Small, S. Morphogen rules: Design principles of gradient-mediated embryo patterning. Development 2015, 142, 3996-4009. Available online: http://www.ncbi.nlm.nih.gov/pubmed/26628090 (accessed on 2 July 2021). [CrossRef]

168. Stamataki, D.; Ulloa, F.; Tsoni, S.V.; Mynett, A.; Briscoe, J. A gradient of Gli activity mediates graded Sonic Hedgehog signaling in the neural tube. Genes Dev. 2005, 19, 626-641. Available online: http:/ / www.ncbi.nlm.nih.gov/entrez/query.fcgi?cmd=Retrieve\& $\mathrm{db}=$ PubMed\&dopt=Citation\&list_uids=15741323 (accessed on 2 July 2021). [CrossRef] [PubMed]

169. Cayuso, J.; Ulloa, F.; Cox, B.; Briscoe, J.; Marti, E. The Sonic hedgehog pathway independently controls the patterning, proliferation and survival of neuroepithelial cells by regulating Gli activity. Development 2006, 133, 517-528. Available online: http://www.ncbi.nlm.nih.gov/entrez/query.fcgi?cmd=Retrieve\&db=PubMed\&dopt=Citation\&list_uids=16410413 (accessed on 2 July 2021). [CrossRef] 
170. Charrier, J.B.; Lapointe, F.; Le Douarin, N.M.; Teillet, M.A. Anti-apoptotic role of Sonic hedgehog protein at the early stages of nervous system organogenesis. Development 2001, 128, 4011-4020. [CrossRef]

171. Feng, X.; Adiarte, E.G.; Devoto, S.H. Hedgehog acts directly on the zebrafish dermomyotome to promote myogenic differentiation. Dev. Biol. 2006, 300, 736-746. Available online: http://www.ncbi.nlm.nih.gov/entrez/query.fcgi?cmd=Retrieve\&db=PubMed\& dopt $=$ Citation\&list_uids $=17046741$ (accessed on 2 July 2021). [CrossRef]

172. Hammond, C.L.; Hinits, Y.; Osborn, D.P.; Minchin, J.E.; Tettamanti, G.; Hughes, S.M. Signals and myogenic regulatory factors restrict pax3 and pax7 expression to dermomyotome-like tissue in zebrafish. Dev. Biol. 2007, 302, 504-521. Available online: http: / / www.ncbi.nlm.nih.gov / entrez/query.fcgi?cmd=Retrieve\&db=PubMed\&dopt=Citation\&list_uids=17094960 (accessed on 2 July 2021). [CrossRef]

173. Maurya, A.K.; Tan, H.; Souren, M.; Wang, X.; Wittbrodt, J.; Ingham, P.W. Integration of Hedgehog and BMP signalling by the engrailed2a gene in the zebrafish myotome. Development 2011, 138, 755-765. Available online: http://www.ncbi. nlm.nih.gov/entrez/query.fcgi?cmd=Retrieve\&db=PubMed\&dopt=Citation\&list_uids=21266411 (accessed on 2 July 2021). [CrossRef] [PubMed]

174. Wolff, C.; Roy, S.; Ingham, P.W. Multiple muscle cell identities induced by distinct levels and timing of hedgehog activity in the zebrafish embryo. Curr. Biol. 2003, 13, 1169-1181. [CrossRef]

175. Teillet, M.A.; Watanabe, Y.; Jeffs, P.; Duprez, D.; Lapointe, F.; Le Douarin, N.M. Sonic hedgehog is required for survival of both myogenic and chondrogenic somitic lineages. Development 1998, 125, 2019-2030. [CrossRef]

176. Borycki, A.G.; Brunk, B.; Tajbakhsh, S.; Buckingham, M.; Chiang, C.; Emerson, C.P., Jr. Sonic hedgehog controls epaxial muscle determination through Myf5 activation. Development 1999, 126, 4053-4063. Available online: http:/ /www.ncbi.nlm.nih.gov/ entrez/query.fcgi?cmd=Retrieve\&db=PubMed\&dopt=Citation\&list_uids=10457014 (accessed on 2 July 2021). [CrossRef]

177. Amthor, H.; Christ, B.; Patel, K. A molecular mechanism enabling continuous embryonic muscle growth-A balance between proliferation and differentiation. Development 1999, 126, 1041-1053. [CrossRef]

178. Blagden, C.S.; Hughes, S.M. Extrinsic influences on limb muscle organisation. Cell Tissue Res. 1999, 296, 141-150. [CrossRef] [PubMed]

179. Du, S.J.; Devoto, S.H.; Westerfield, M.; Moon, R.T. Positive and negative regulation of muscle cell identity by members of the hedgehog and TGF-beta gene families. J. Cell Biol. 1997, 139, 145-156. Available online: http:/ / www.ncbi.nlm.nih.gov/entrez/ query.fcgi?cmd=Retrieve\&db=PubMed\&dopt=Citation\&list_uids=9314535 (accessed on 2 July 2021). [CrossRef]

180. Kahane, N.; Cinnamon, Y.; Kalcheim, C. The origin and fate of pioneer myotomal cells in the avian embryo. Mech. Dev. 1998, 74, 59-73. [CrossRef]

181. Kahane, N.; Ben-Yair, R.; Kalcheim, C. Medial pioneer fibers pattern the morphogenesis of early myoblasts derived from the lateral somite. Dev. Biol. 2007, 305. [CrossRef] [PubMed]

182. Ben-Yair, R.; Kahane, N.; Kalcheim, C. LGN-dependent orientation of cell divisions in the dermomyotome controls lineage segregation into muscle and dermis. Development 2011, 138. [CrossRef]

183. Buckingham, M.; Montarras, D. Skeletal muscle stem cells. Curr. Opin. Genet. Dev. 2008, 18, 330-336. Available online: http:/ / www.ncbi.nlm.nih.gov / entrez/query.fcgi?cmd=Retrieve\&db=PubMed\&dopt=Citation\&list_uids=18625314 (accessed on 2 July 2021). [CrossRef]

184. Relaix, F.; Rocancourt, D.; Mansouri, A.; Buckingham, M. A Pax3/Pax7-dependent population of skeletal muscle progenitor cells. Nature 2005, 435, 948-953. [CrossRef]

185. Chiang, C.; Litingtung, Y.; Lee, E.; Young, K.E.; Corden, J.L.; Westphal, H.; Beachy, P.A. Cyclopia and defective axial patterning in mice lacking Sonic hedgehog gene function. Nature 1996, 383, 407-413. [CrossRef]

186. Dockter, J.; Ordahl, C.P. Dorsoventral axis determination in the somite: A re-examination. Development 2000, 127, 2201-2206. [CrossRef] [PubMed]

187. Fan, C.-M.; Tessier-Lavigne, M. Patterning of mammalian somites by surface ectoderm and notochord: Evidence for sclerotome induction by a hedgehog homolog. Cell 1994, 79, 1175-1186. [CrossRef]

188. Kahane, N.; Kalcheim, C. Neural tube development depends on notochord-derived sonic hedgehog released into the sclerotome. Development 2020, 147. [CrossRef]

189. Stafford, D.A.; Brunet, L.J.; Khokha, M.K.; Economides, A.N.; Harland, R.M. Cooperative activity of noggin and gremlin 1 in axial skeleton development. Development 2011, 138, 1005-1014. [CrossRef] [PubMed]

190. Huang, R.J.; Zhi, Q.X.; Schmidt, C.; Wilting, J.; Brand-Saberi, B.; Christ, B. Sclerotomal origin of the ribs. Development 2000, 527-532. [CrossRef]

191. Kalcheim, C.; Ben-Yair, R. Cell rearrangements during development of the somite and its derivatives. Curr. Opin. Genet. Dev. 2005, 15. [CrossRef]

192. Dubrulle, J.; Pourquie, O. Welcome to syndetome: A new somitic compartment. Dev. Cell 2003, 4, 611-612. Available online: http:/ / www.ncbi.nlm.nih.gov/entrez/query.fcgi?cmd=Retrieve\&db=PubMed\&dopt=Citation\&list_uids=12737797 (accessed on 2 July 2021). [CrossRef]

193. Choi, K.S.; Harfe, B.D. Hedgehog signaling is required for formation of the notochord sheath and patterning of nuclei pulposi within the intervertebral discs. Proc. Natl. Acad. Sci. USA 2011, 108, 9484-9489. [CrossRef]

194. Dietrich, S.; Gruss, P. undulated phenotypes suggest a role of Pax-1 for the development of vertebral and extravertebral structures. Dev.Biol. 1995, 167, 529-548. [CrossRef] 
195. Wood, W.M.; Otis, C.; Etemad, S.; Goldhamer, D.J. Development and patterning of rib primordia are dependent on associated musculature. Dev. Biol. 2020, 468, 133-145. [CrossRef] [PubMed]

196. Grifone, R.; Demignon, J.; Houbron, C.; Souil, E.; Niro, C.; Seller, M.J.; Hamard, G.; Maire, P. Six1 and Six4 homeoproteins are required for Pax3 and Mrf expression during myogenesis in the mouse embryo. Development 2005, 132, 2235-2249. [CrossRef] [PubMed]

197. Elefteriou, F. Impact of the autonomic nervous system on the skeleton. Physiol. Rev. 2018, 98, 1083-1112. [CrossRef] [PubMed]

198. Vyas, N.; Walvekar, A.; Tate, D.; Lakshmanan, V.; Bansal, D.; Lo Cicero, A.; Raposo, G.; Palakodeti, D.; Dhawan, J. Vertebrate Hedgehog is secreted on two types of extracellular vesicles with different signaling properties. Sci. Rep. 2014, 4, 7357. Available online: http:/ / www.ncbi.nlm.nih.gov/pubmed/25483805 (accessed on 2 July 2021). [CrossRef]

199. Dierker, T.; Dreier, R.; Petersen, A.; Bordych, C.; Grobe, K. Heparan sulfate-modulated, metalloprotease-mediated sonic hedgehog release from producing cells. J. Biol. Chem. 2009, 284, 8013-8022. Available online: http://www.ncbi.nlm.nih.gov/pubmed/1917 6481 (accessed on 2 July 2021). [CrossRef] [PubMed]

200. Chen, M.H.; Li, Y.J.; Kawakami, T.; Xu, S.M.; Chuang, P.T. Palmitoylation is required for the production of a soluble multimeric Hedgehog protein complex and long-range signaling in vertebrates. Genes Dev. 2004, 18, 641-659. Available online: http: / / www.ncbi.nlm.nih.gov/pubmed/15075292 (accessed on 2 July 2021). [CrossRef] [PubMed]

201. Parchure, A.; Vyas, N.; Mayor, S. Wnt and Hedgehog: Secretion of Lipid-Modified Morphogens. Trends Cell Biol. 2018, 28, 157-170. Available online: http://www.ncbi.nlm.nih.gov/pubmed/29132729 (accessed on 2 July 2021). [CrossRef]

202. Callejo, A.; Torroja, C.; Quijada, L.; Guerrero, I. Hedgehog lipid modifications are required for Hedgehog stabilization in the extracellular matrix. Development 2006, 133, 471-483. Available online: http:/ /www.ncbi.nlm.nih.gov/pubmed/16396909 (accessed on 2 July 2021). [CrossRef]

203. Etoc, F.; Metzger, J.; Ruzo, A.; Kirst, C.; Yoney, A.; Ozair, M.Z.; Brivanlou, A.H.; Siggia, E.D. A Balance between Secreted Inhibitors and Edge Sensing Controls Gastruloid Self-Organization. Dev. Cell 2016, 39, 302-315. Available online: http: / / www.ncbi.nlm.nih.gov/pubmed/27746044 (accessed on 2 July 2021). [CrossRef]

204. Phan-Everson, T.; Etoc, F.; Li, S.; Khodursky, S.; Yoney, A.; Brivanlou, A.H.; Siggia, E.D. Differential compartmentalization of BMP4/NOGGIN requires NOGGIN trans-epithelial transport. Dev. Cell 2021, 56, 1930.e5-1944.e5. [CrossRef] 